Notre Dame Law School

NDLScholarship

Journal Articles

Publications

2003

\title{
Subsidiarity as a Structural Principle of International Human Rights Law
}

Paolo G. Carozza

Notre Dame Law School, pcarozza@nd.edu

Follow this and additional works at: https://scholarship.law.nd.edu/law_faculty_scholarship

Part of the Human Rights Law Commons, and the International Law Commons

\section{Recommended Citation}

Paolo G. Carozza, Subsidiarity as a Structural Principle of International Human Rights Law, 97 Am. J. Int'l L. 38 (2003).

Available at: https://scholarship.law.nd.edu/law_faculty_scholarship/564

This Article is brought to you for free and open access by the Publications at NDLScholarship. It has been accepted for inclusion in Journal Articles by an authorized administrator of NDLScholarship. For more information, please contact lawdr@nd.edu. 
This article is reproduced with permission from the January 2003 issue of the American Journal of International Law ( 2003 American Society of International Law. All rights reserved.

\title{
SUBSIDIARITY AS A STRUCTURAL PRINCIPLE OF INTERNATIONAL HUMAN RIGHTS LAW
}

\author{
By Paolo G. Carozza*
}

Every individual should say the phrase of Louis XIV: "I am the state."

$$
\text { - Rudolf von Jhering }
$$

Where, after all, do universal human rights begin? In small places, close to home-so close and so small that they cannot be seen on any map of the world. Yet they are the world of the individual person: the neighborhood he lives in; the school or college he attends; the factory, farm or office where he works. Such are the places where every man, woman, and child seeks equal justice, equal opportunity, equal dignity without discrimination. Unless these rights have meaning there, they have little meaning anywhere.

- Eleanor Roosevelt

There is an inherent tension in international human rights law between affirming a universal substantive vision of human dignity and respecting the diversity and freedom of human cultures. Although understanding and securing human rights in international law requires us to grapple with that conflict, classic notions of state sovereignty cannot adequately address the issue. The principle of subsidiarity, ${ }^{1}$ instead, gives us a conceptual tool to mediate the polarity of pluralism and the common good in a globalized world and helps us make sense of international human rights law. I argue that we should regard subsidiarity as a structural principle of international human rights law.

Although the idea of subsidiarity is rooted deep in the history of Western political thought, it has grown visible as a prominent political and legal concept only much more recently. Thanks to the European Union's adoption of subsidiarity as one of its central constitutional principles, in the last decade the term has emerged from the narrower confines of German law and the social philosophy of the Catholic Church. To those outside the field of European law the word may still have a somewhat awkward, Eurospeak ring to it, like a thin and less filling analogue to the meatier term "federalism."2 Nevertheless, the idea is increasingly relevant to a

\footnotetext{
"Associate Professor of Law, University of Notre Dame. I would like to thank Patti Ogden, Anna Ursano, and Angela Priest for their research assistance, as well as John Coughlin, Patti Ogden, John Robinson, Vincent Rougeau, and John Wauck for their helpful comments on prior drafts.

The sources of the epigraphs to this article are Lorenza Violini, Il Principio di sussidiarietà, in SUSSIDIARIETÀ: LA RIFORMA POSSIBILE 53, 57 (Giorgio Vittadini ed., 1998) (quoting Rudolf von Jhering) (my trans.); Eleanor Roosevelt, In Your Hands, Address at the United Nations (Mar. 27, 1958), at<htttp://www.udhr.org/history/inyour.htm>.

${ }^{1}$ Although I will show below that the concept is considerably more complex, for now a very simplified working definition can suffice: subsidiarity is the principle that each social and political group should help smaller or more local ones accomplish their respective ends without, however, arrogating those tasks to itself.

${ }^{2}$ Much of the American literature on subsidiarity focuses especially on its comparison to United States federalism. George Bermann's early and exhaustive study is still the standard-bearer of this work. George A. Bermann, Taking Subsidiarity Seriously: Federalism in the European Community and the United States, 94 COLUM. L. REV. 332,336 (1994); see also Denis J. Edwards, Fearing Federalism's Failure: Subsidiarity in the European Union, 44 AM. J. CoMP. L. 537 (1996); Gerald L. Neuman, Subsidiarity, Harmonization, and Their Values: Convergence and Divergence in Europe and the United States, 2 CoLUM. J. EUR. L. 573 (1996); W. Gary Vause, The Subsidiarity Principle in European Union LawAmerican Federalism Compared, 27 CASE W. RES. J. INT'L L. 61 (1995).
} 
variety of substantive areas of law and governance, ${ }^{3}$ and is finding a place in the constitutional discourse of many legal systems other than the European Union (EU). ${ }^{4}$

With the adoption of the Charter of Fundamental Rights of the European Union (the Charter) in December 2000, subsidiarity was formally extended for the first time into the arena of human rights. ${ }^{5}$ Nevertheless, it remains unclear what the relationship between subsidiarity and human rights will prove to be in the European Union. Until now, the constitutional limitations of the Union have constrained the potential intersections between them, and scholars have accorded subsidiarity only passing references in discussions of EU human rights law. ${ }^{6}$ Although the European Court of Justice (ECJ) can be regarded as tacitly addressing some elements of subsidiarity in its fundamental rights case law, it has never done so explicitly, and in any case the principle has significant dimensions beyond those that can be seen in the Court's jurisprudence. Thus, although the Union provides one necessary piece of the inquiry, to understand more fully the rich contribution that the concept of subsidiarity can make to international human rights law generally requires looking beyond Europe.

I begin, therefore, with a discussion of the theoretical foundations of the principle of subsidiarity generally (part I) ${ }^{7}$ The concept is not a rigid or precise one, and it is characterized by internal tensions and inherent paradoxes that need to be identified, especially its combination of intervention with noninterference. When used in its original and most comprehensive sense, subsidiarity has deep affinities at its roots with many of the implicit premises of international human rights norms, including presuppositions about the dignity and freedom of human persons, the importance of their association with others, and the role of the state with respect to smaller social groups as well as individuals.

Going beyond the jurisprudential background to positive law, the constitutional system of the European Union helps illustrate that subsidiarity (especially when understood as a

\footnotetext{
${ }^{3}$ See, e.g., Annette Klimisch \& Birgit Krueger, Decentralized Application of E. C. Competition Law: Current Practice and Future Prospects, 24 EUR. L. REv. 463 (1999); Koen Lenaerts, The Principle of Subsidiarity and the Environment in the European Union: Keeping the Balance of Federalism, 17 FORDHAM INT'L L.J. 846 (1994); William Murray Tabb, Environmental Impact Assessment in the European Community: Shaping International Norms, 73 TUL. L. REV. 923 (1999); Rein Wesseling, Subsidiarity in Community Antitmust Law: Setting the Right Agenda, 22 EUR. L. REV. 35 (1997).

${ }^{4}$ See generally SUSSIDIARIETÀ E ORDINAMENTI COSTITUZIONALI: ESPERIENZE A CONFRONTO (A. Rinella et al. eds., 1999) (describing subsidiarity in a variety of different constitutional systems). With respect to the lively debate in Italy over the principle of subsidiarity as a constitutional concept, see SUSSIDIARIETA்: LA RIFORMA POSSIBILE, supra note *.

${ }^{5}$ The preamble "reaffirms, with due regard for the powers and tasks of the Community and the Union and the principle of subsidiarity," the rights resulting from a variety of other sources of law, and the Charter also specifies in Article 51 that it is "addressed to the institutions and bodies of the Union with due regard for the principle of subsidiarity." Charter of Fundamental Rights of the European Union, 2000 O.J. (C 364) 1 [hereinafter Charter].

${ }^{6}$ See, e.g., Philip Alston \& Joseph H. H. Weiler, An 'Ever Closer Union' in Need of a Human Rights Policy: The Eurapean Union and Human Rights, in THE EU AND HUMAN RIGHTS 3, 27 (Philip Alston ed., 1999), available at <http:// www.jeanmonnetprogram.org/papers/papers99.html>.

${ }^{7}$ At this level, the relationship between subsidiarity and human rights is almost entirely unexplored, both within EU law and even more outside it. But see Larry Catá Backer, Harmonization, Subsidiarity and Cultural Difference: An Essay on the Dynamics of Opposition Within Federative and International Legal Systems, 4 TULSA J. COMP. \& INT'L L. 185 (1997); Daniel T. Murphy, Subsidiarity and/or Human Rights, 29 U. RICH. L. REV. 67 (1994); Dinah Shelton, Subsidiarity, Democracy and Human Rights, in BROADENING THE FRONTIERS OF HUMAN RIGHTS: ESSAYS IN HONOUR OF ASBJøRN EIDE 43 (Donna Gomien ed., 1993). Many authors who have addressed "subsidiarity" in the context of human rights have in effect used the term to refer to ideas only partially related to the principle of subsidiarity in its fuller and original sense, as I seek to use it here. Very commonly, for example, "subsidiarity" is used to refer to the relationship between certain international human rights treaties and domestic law, represented by clauses common to human rights treaties that say, basically, that nothing in the treaty shall limit or restrict rights and freedoms guaranteed under the national law of a state party; such provisions make the international agreement "subsidiary" to domestic law, and hence it is not uncommon to refer to the relationship as a form of "subsidiarity." See, e.g., Leonard F. M. Besselink, Entrapped by the Maximum Standard: On Fundamental Rights, Pluralism and Subsidiarity in the European Union, 35 COMMON MKr. L. REV. 629 (1998). Others, especially in the context of the Council of Europe's human rights system, have used "subsidiarity" as a synonym for the European Court of Human Rights' doctrine of the margin of appreciation, or to refer generally to the idea of devolving decisions to local authorities. See, e.g., Paul Mahoney, Universality Versus Subsidiarity in the Strasbourg Case Law on Free Speech: Explaining Some Recent Judg. ments, 1997 EUR. HUM. RTS. L.R. 364.
} 
general principle rather than a technical rule) functions as a conceptual and rhetorical mediator between supranational harmonization and unity, on the one hand, and local pluralism and difference, on the other. Part II explores this connection, and the ways it is reflected in EU fundamental rights law. However, my concern here is not to develop the place of subsidiarity in the constitutional structure of the European Union but, instead, to use EU law as a stepping-stone to consider the principle's potential place in international human rights law more broadly, in part III.

As in the European Union, in international law subsidiarity can be understood to be a conceptual alternative to the comparatively empty and unhelpful idea of state sovereignty. The principle of subsidiarity provides an analytically descriptive way to make sense of a variety of disparate features of the existing structure of international human rights law, from the interpretive discretion accorded to states, to the relationship of regional and universal systems, while also justifying the necessity of international cooperation, assistance, and intervention. In fact, subsidiarity fits international human rights law so well that the basic values of the principle can' reasonably be regarded as already implicitly present in the structure of international human rights law. If that is correct, then it is not surprising to find in the development of human rights law that other doctrines and ideas have arisen that function at least in part as analogues to subsidiarity in addressing the pervasive dialectic between universal human rights norms and legitimate claims to pluralism. The doctrine of the "margin of appreciation," first developed by the European Court of Human Rights (ECHR), is the most notable example. But a direct comparison of subsidiarity to the existing techniques for accommodating diversity shows that the comprehensiveness and jurisprudential grounding of subsidiarity make it a more powerful concept for understanding and developing international human rights law.

The principal advantage of subsidiarity as a structural principle of international human rights law is that it integrates international, domestic, and subnational levels of social order on the basis of a substantive vision of human dignity and freedom, while encouraging and protecting pluralism among them. For those most committed to uniformity and universality in human rights, however, the pluralism that subsidiarity envisions also raises several potential dangers. Philosophically, it might be thought to call into question the senses in which human rights can be considered "fundamental," "universal," and ultimately even "human." Politically, one might reasonably question whether subsidiarity will merely weaken the practical effectiveness of international human rights law. And, finally, subsidiarity suggests a challenge for the legal values of certainty and consistency that come from uniformity. Part IV continues with a brief consideration of some of these objections to the application of subsidiarity to human rights, concluding that recognizing and applying the principle of subsidiarity should actually strengthen international human rights in both theory and practice. Despite the risks of legal pluralism, the links between subsidiarity and human rights are too important and potentially fruitful to set aside if we are to continue to seek an international law that protects both the dignity of the human person and the diversity of human society.

\section{THE IDEA OF SUBSIDIARITY}

\section{The Initial Formulation of the Concept}

Even though the word "subsidiarity" entered our political lexicon only in the twentieth century, the idea has an intellectual history as old as European political thought. Chantal Millon-Delsol, whose study of subsidiarity is one of the most comprehensive available and one of the first standard sources for any study of the concept, traces its origins as far back 
as classical Greece, ${ }^{8}$ and finds it later taken up by Thomas Aquinas and medieval scholasticism. ${ }^{9}$ Johannes Althusius developed the principle in connection with his theories of the secular federal state in the seventeenth century, ${ }^{10}$ and one can find subsequent echoes of it in the thought of political actors and theorists as varied as Montesquieu, Locke, Tocqueville, Lincoln, and Proudhon. ${ }^{11}$

It was only in the latter part of the nineteenth century that Catholic social theorists became the principal proponents of the idea of subsidiarity, as they sought some sort of middle way between the perceived excesses of both laissez-faire liberal capitalist society and Marxian socialist alternatives. ${ }^{12}$ That intellectual current led directly to the first papal encyclical on the "social question," Leo XIII's Rerum Novanum, in $1891 .{ }^{13}$ Rerum Novarum was primarily concerned with the conditions of workers, emphasizing the need for state intervention to protect them, for instance, by guaranteeing a just wage and the freedom to organize for collective bargaining. Yet, in opposition to socialist models of state and society, the encyclical argued that justifiable state intervention was limited in nature. Thus, Leo wrote, "Whenever the general interest or any particular class suffers, or is threatened with harm, which can in no other way be met or prevented, the public authority must step in to deal with it"; but the limits of that intervention "must be determined by the nature of the occasion which calls for the law's interference-the principle being that the law must not undertake more, nor proceed further, than is required for the remedy of the evil or the removal of the mischief." 14

Already in this early formulation, we can see some tension inherent in the principle being articulated. The public authority is obliged to intervene to assist workers (or the family, etc.), yet must not intrude to the point of absorbing or destroying them, or preventing them from accomplishing what they can on their own. Still, the emphasis of Rerum Novarum definitely falls more on the side of public assistance; its principal purpose was to justify and encourage the protection of workers from the effects of unrestrained capitalism. In 1931, when one of Leo's successors, Pius XI, wrote on the occasion of the fortieth anniversary of Rerum Novarum (which Pius referred to as "the Magna Charta" of Christian social action ${ }^{15}$ ), the political circumstances of course were dramatically different, dominated more by the rising threat of totalitarianism than by the failure of the state to protect the constituent parts of society. In his encyclical Quadragesimo Anno, Pius reformulated the Rerum Novarum principle of intervention-but-not-interference with a decidedly stronger emphasis on the limits of public authority. He also expressed the idea of subsidiarity both more amply and more precisely, and thus provided the starting point for all subsequent uses and adaptations of the principle. It is therefore worth quoting the relevant passage in full:

\footnotetext{
${ }^{8}$ Chantal Millon-Delsol, L'Etat subsidiaire: IngÉrence et nON-INGÉrence de L'ETAT: Le Principe de SUBSIDIARITÉ AUX FONDEMENTS DE L'HISTOIRE EUROPÉENNE 15-27 (1992).

${ }^{9} I d$. at $35-45$.

${ }^{10}$ Id. at 47-60; see also Ken Endo, The Principle of Subsidiarity: From Johannes Althusius to Jacques Delors, 44 HOKKAIDO L. REV. 2064, 2043 (1994).

${ }^{11}$ Millon-Delsol, supra note 8; Endo, supra note 10; see also Angelo Rinella, Il Principio di sussidiarietà: Definizioni, comparazioni e modello d'analisi, in SUSSIDIARIETȦ E ORDINAMENTI COSTITUZIONALI: ESPERIENZE A CONFRONTO, supra note 4, at 3,8-18. Benjamin Llamazon, instead, traces the lineage of the idea from Plato and Aristotle, through Augustine to von Humboldt, Mill, and Nietzsche. Benjamin S. Llamazon, Subsidiarity: The Term, Its Metaphysics and Use, 21 AQUINAS: RIVISTA INTERNAZIONALE DI FILOSOFIA 44, 47 (1978).

${ }^{12}$ See Thomas C. Kohler, Quadragesimo Anno (1931), in A CENTURY OF CATHOLIC Social ThOUght: EsSAYS ON RERum Novarum AND Nine OTHER KEY DocumEnTs 27, 29-30 (George Weigel \& Robert Royal eds., 1991); $c f$. MILLON-DELSOL, supra note 8, at 5 ("The idea of subsidiarity.... aims at going beyond the alternative between classic liberalism and centralizing socialism .... [I] t abandons socialist egalitarianism in favor of the value of dignity; it abandons philosophical individualism in favor of a structured and federated society.") (my trans.).

${ }^{13}$ Leo XIII, Rerum Novarum: Encyclical Letter on Capital and Labor (May 15, 1891), in 2 THE PAPAL ENCYCLICALS 1878-1903, at 241 (Claudia Carlen ed., 1990). Papal encyclicals are typically denominated by the first few words of their Latin texts; in this case, Rerum Novarum means "New Things."

${ }^{14}$ Id. at 250-51, para. 36.

${ }^{15}$ Pius XI, Quadragesimo Anno: Encyclical Letter on Recomstruction of Social Order (May 15, 1931), in 3 THE PAPAL ENCYC LICALS 1903-1939, supra note 13, at 421, para. 39.
} 
As history abundantly proves, it is true that on account of changed conditions many things which were done by small associations in former times cannot be done now save by large associations. Still, that most weighty principle, which cannot be set aside or changed, remains fixed and unshaken in social philosophy: Just as it is gravely wrong to take from individuals what they can accomplish by their own initiative and industry and give it to the community, so also it is an injustice and at the same time a grave evil and disturbance of right order to assign to a greater and higher association what lesser and subordinate organizations can do. For every social activity ought of its very nature to furnish help ${ }^{16}$ to the members of the body social, and never destroy and absorb them.

... The supreme authority of the State ought, therefore, to let subordinate groups handle matters and concerns of lesser importance, which would otherwise dissipate its efforts greatly. Thereby the State will more freely, powerfully, and effectively do all those things that belong to it alone because it alone can do them: directing, watching, urging, restraining, as occasion requires and necessity demands. Therefore, those in power should be sure that the more perfectly a graduated order is kept among the various associations, in observance of the principle of "subsidiary function," the stronger social authority and effectiveness will be [and] the happier and more prosperous the condition of the State. ${ }^{17}$

The principle articulated in these two paragraphs presupposes several underlying and interwoven ideas about the individual, the state, and society. Although the aim here is not to defend them philosophically, to understand better the connections between subsidiarity and human rights it is important to identify how subsidiarity results from the confluence of certain more fundamental premises.

\section{The Premises and Contours of the Idea of Subsidiarity}

Even though some contemporary discussion, especially in the European Union, might suggest otherwise, subsidiarity does not derive its force from an instrumental concern for social efficiency or a need for political compromise. Its basis is personalistic, rather than contractual or utilitarian. ${ }^{18}$ That is, its first foundation is a conviction that each human individual is endowed with an inherent and inalienable worth, or dignity, ${ }^{19}$ and thus that the value of the individual human person is ontologically and morally prior to the state or other social groupings. ${ }^{20}$ Because of this value, all other forms of society, from the family to the state and the international order, ought ultimately to be at the service of the human person. Their end must be the flourishing of the individual.

An ultimate orientation toward the individual does not, however, imply that subsidiarity represents a classically libertarian view of society as an aggregation of radically autonomous units, for several reasons. First, subsidiarity presupposes that the human person toward whose flourishing the application of the principle is aimed is naturally social. ${ }^{21}$ Her dignity requires

\footnotetext{
${ }^{16}$ In the Latin text, for the word "help" Pius used subsidium. Pius XI, Litterae Encyclicae Quadragesimo Anno, in 23 ACTA APOSTOLICAE SEDIS 177, 203 (1931). The Latin term originated in the ancient Roman military-the subsidium was that portion of the troops held in reserve, to be able to assist the front lines when in need-but came also to mean more generally "support," "help," "assistance," or "protection." See OXFORd LATIN DiCTIONARY 1849 (P. G. W. Glare ed., 1982).

${ }^{17}$ Pius XI, supra note 15 , at 428 , paras. $79-80$.

${ }^{18}$ See Filippo Pizzolato, Note sul principio di sussidiarietà, 12 Rivista InTERNaZionale dei DiRITTI DELL'UOMO 493 (1999).

${ }^{19}$ See Endo, supra note 10, at 2029-26.

${ }^{20}$ See Llamazon, supra note 11 , at 45, 49, 56

${ }^{21}$ See Clifford Kossel, Global Community and Subsidiarity, 8 Communio: InT'L CATH. Rev. 37, 46 (1981). Although the notion here of man as a social being by nature is basically Aristotelian, at the same time it can be thought to turn on its head Aristotle's conclusion that the polis exists prior to the individual. ARISTOTLE, POLITICS, bk. I, ch. $2, \S \S 5-16$.
} 
relationship with others, in a variety of ways and settings, from family life to political participation. While she can never be reduced merely to a part of a social whole, because of the value of the individual person as such, still her fulfillment will be realized only in association with other people. ${ }^{22}$ Thus, to put the point another way, association with others makes it possible for the person to become more authentically human, and her relationship with others cannot be separated from the full expression and realization of her inherent and primary value. One could say that the existence and end of the community (and this can mean a "community" as intimate as a single friendship) is to help the individual flourish, to help create the conditions for her to reach her ultimate fulfillment.

The idea of subsidiarity extends that same model of fulfillment through relationship and assistance to all levels of social interaction. ${ }^{23}$ It envisions that just as the individual realizes his fulfillment in community with others, so do smaller communities realize their purpose in interactions with other groups-a group of families as part of an educational community, for instance, or a group of workers as part of an economy of production and exchange. And, in turn, the "higher" ${ }^{24}$ groupings exist not just for their own sake but to assist the smaller, more limited associations in realizing their tasks, just as the community of a friendship or family is oriented toward providing the individual with the conditions enabling him to realize freely his own dignity. Here, then, is the second sense in which the understanding of social and political order that the concept of subsidiarity envisions is not a classically libertarian one. The various human associations that constitute society (to the extent that they are healthy and functioning properly) are seen to fit together organically. ${ }^{25}$ In one direction, each larger grouping is understood to serve the smaller, and all in the end are understood to serve individual dignity; in the other direction, not only the individual, but also each level of human association is understood to be linked, by its very structure and purpose, to a "higher" one.

The third significant difference between the idea of subsidiarity and a more libertarian vision of social organization lies in the conception of freedom that is at stake. Subsidiarity does presuppose that human flourishing requires freedom. An individual must be free to realize her own destiny through her own initiative, her own response to the circumstances that her life presents to her in concrete historical choices. This reality, according to one author, is "the deepest foundation of the doctrine" of subsidiarity. ${ }^{26}$ Thus, respecting the dignity of the human person and the integrity of the groups that constitute his or her personhood (and that themselves have a certain integrity) requires that all forms of society be oriented toward the freedom of "lower" forms of association, and ultimately toward the freedom of the individual. In short, subsidiarity takes the freedom necessary to human dignity and extends it to a regard for freedom at all levels of social organization.

This freedom, however, is not simply a negative notion of restraint from interference; it also encompasses an affirmative dimension. It means freedom to act in such a way as to participate fully in the goods of an authentically human life. ${ }^{27}$ Thus, since freedom is understood as the ability to reach one's complete flourishing, to realize the capacities of a being of inherent dignity, it can also be served by an intervention that creates the necessary conditions

\footnotetext{
${ }^{22}$ Endo, supra note 10, at 2026 (noting that subsidiarity presupposes that "societies are necessary for the development of any person, therefore for the "concretisation' of human dignity") (footnote omitted).

${ }^{29}$ Cf. Pizzolato, supra note 18, at 498 ("Starting from this conception of man as a being structurally open to solidary relationships, ... subsidiarity becomes an ordering principle for living together in a way that aspires to be just and to extend itself potentially to everyone.") (my trans.).

24 "Higher" here refers to an association whose scope and authority are broader, thus more completely expressive of the total ambit of human interactions. One could say "larger" instead, even though the size of the group is not, of itself, at issue.

${ }^{25}$ Cf. Pizzolato, supra note 18 , at 497 (relating subsidiarity to "organicism").

${ }^{263}$ Llamazon, supra note 11 , at 56.

${ }^{27}$ JOHN FINNIS, NATURAL. LAW AND NATURAL RIGHTS 147 (1980) (arguing that the source of the principle of subsidiarity is that "only in action ... does one fully participate in human goods").
} 
for the individual to lead a life of purpose and fulfillment. To give a concrete example, if an individual's human dignity is served by realizing her creativity and dynamic drive through work, then creating the conditions that make it possible for her to find and pursue work would be an enhancement of her freedom to realize her dignity. And given the organic relationship of individuals and associations discussed above, this notion of freedom can be extended to all levels of society: for each group, as for each individual, its freedom is furthered in a comprehensive sense by satisfying the conditions necessary for it to accomplish its ends.

From those premises, the articulation of the principle of subsidiarity draws several conclusions about the responsibilities and limitations of the state.$^{28}$ The most familiar one-most commonly emphasized, for instance, in discussions of subsidiarity in the European Unionis the obligation of the government to limit its intervention into lower forms of social organization, and to do only that which the lesser group cannot accomplish for itself without assistance. Since each level of society is responsible for helping the "lower" one freely to accomplish its aims, it would contravene that relationship if the "higher" association arrogated to itself those tasks which can be effectively undertaken by a group that is closer to the individual. This aspect of the general principle might be referred to as the "negative" dimension of subsidiarity. ${ }^{29}$

However, the same premises also lead to "positive subsidiarity," 30 justifying intervention by the state in situations where "lower" forms of organization cannot achieve their ends by themselves. In fact, subsidiarity insists not only that the state may intervene in such situations, but that it has "an inherent right" to concern itself with the common good ${ }^{31}$ and indeed a duty to exercise that right. "This is the supplement, the subsidium, which the political community must give to others, a help that does not destroy them but enables them to perform their own functions better and thus to contribute to the common good of all." 33

Subsidiarity is therefore a somewhat paradoxical principle. It limits the state, yet empowers and justifies it. It limits intervention, yet requires it. It expresses both a positive and a negative vision of the role of the state with respect to society and the individual. That duality appeared in the first variations of the principle articulated by Leo XIII and Pius XI, and is still evident in much of the disagreement about the proper application of the principle today. This understanding of subsidiarity as a combination of two conflicting ideas is a central theme of Millon-Delsol's study:

The first [aspect of subsidiarity] calls for the respect of liberties as far as possible; it calls for noninterference by authority. Conversely, the second assumes interference by authority both to guarantee a sort of social unity and to help organize interdependent bonds. The first demands that variety be recognized both as essence and as norm. The second demands that communion be lived as an object, as a goal. The first thrives on distributive justice, the second on social justice . . . Nevertheless, the principle of subsidiarity reunites these antitheses, and affirms them jointly. Subsidiarity is the locus of a paradox that it takes up in a specific way. It exists only because this paradox exists. ${ }^{34}$

In part because of this ambivalent stance toward the roles of the state and other social bodies, the idea of subsidiarity does not demand any specific form of political or economic organization. Clearly, any form of totalitarian impulse that seeks to subsume every individual

\footnotetext{
${ }^{28}$ These do not apply only to the state, of course. Because I am most interested in arriving here at the intersections between subsidiarity and human rights, I will focus on the application of subsidiarity to the state, but the prior discussion should make clear that these are principles that would apply to each of the social groups constituting every form of human association.

${ }^{29}$ Endo, supra note 10, at 2054.

${ }^{30}$ Id. at 2053.

${ }^{31}$ Llamazon, supra note 11 , at 59 .

${ }^{32}$ Kossel, supra note 21, at 46.

${ }^{33}$ Id.

${ }^{34}$ MiLlon-DELSOL, supra note 8 , at 8 (my trans.).
} 
or every social group into the whole is incompatible with the basic presumptions of subsidiarity. ${ }^{35}$ Equally irreconcilable is a political-economic system that abandons individuals to themselves (or to the arbitrary power of, say, the market). Within these boundaries, however, no concrete structure necessarily emerges from a respect for subsidiarity-a majoritarian democracy, for instance, could suppress and usurp the autonomy of its constituent social groups just as a monarchy could govern in a way that respects and assists them. ${ }^{36}$ Here, subsidiarity entails the possibility of pluralism.

In fact, subsidiarity's affirmation of the value of diversity in society, although not as commonly appreciated as other implications of the principle, is strong. This aspect may appear to be another of the paradoxes of subsidiarity. The premises emphasize the integration of all forms of human association and the ultimate unity of their ends in the service of individual human dignity and the common good. Yet, beyond this primary coherence, recognizing the value and necessity of freedom at all levels so as to achieve that dignity also acknowledges that each individual, and every form of association, will instantiate its ends in unique ways, in particular historical and local circumstances. Even the starting premise of subsidiarity, the inherent value of each human person, can be expressed as a recognition that each individual is unique and unrepeatable, thus incapable of being absorbed by any collectivity without doing violence to his inalienable dignity. Likewise, in relationship with others, "the human person, who is to be served by community, is the free and responsible agent who must build and adapt his forms of association to the changing conditions and to his changing awareness of his needs." ${ }^{\mathbf{3 7}}$ Therefore, every community is singular in its identity and dynamics, in the way that it furthers its primary ends-the way, for instance, that a family serves its members' needs for education, material assistance, love, and intimacy. The principle of subsidiarity requires that such expressions of human goods not be supplanted by the state but, instead, be both tolerated and even assisted so as to flourish freely. The end product of this is "greater flexibility and adaptability" in the social order: ${ }^{38}$

Adherence to this principle results in a genuinely pluralistic society, ... which is a union of lesser societies each of which maintains its own identity, function, and end. If the lesser associations are abolished or reduced to mere agencies of the higher, the result is the monolithic state which expresses the essence of social totalitarianism, the reduction of all societies to one omnicompetent society. ${ }^{39}$

Applied comprehensively, therefore, the principle of subsidiarity results in respect for the diversity of human associations, especially (paradoxically, again) as a function of their ultimate unity of purpose. ${ }^{40}$

To the extent that the concept of subsidiarity is taken seriously according to its implicit ideas about the human person and society, it should be apparent that the principle cannot be confined to certain narrow forms of human activity. It is not limited to the market and to maximizing the sphere of rational economic self-interest; nor is it directed merely to fostering

${ }^{35} \mathrm{Cf}$. Llamazon, supra note 11 , at 44-45 (noting subsidiarity's opposition to totalitarianism); Pizzolato, supra note 18 , at 502 (emphasizing incompatibility of subsidiarity with a totalitarian state).

${ }^{36}$ MILLON-DELSOL, supra note 8 , at 9.

${ }^{37}$ Kossel, supra note 21 , at 48.

${ }^{38} I d$.

${ }^{39}$ Id. at 46.

${ }^{40}$ See Llamazon, supra note 11, at 51 (deriving from the common good of society the conclusion that "diversity in society should be given full free play"). But see James W. Skillen \& Rockne M. McCarthy, Three Views of Social Pluralism: A Critical Evaluation, in POLITICAL ORDER AND THE PLURAL STRUCTURE OF SOCIETY 357, 382-89 (James W. Skillen \& Rockne M. McCarthy eds., 1991) (calling into question "the adequacy of the principle of 'subsidiarity' as the normative principle that undergirds social pluralism," and concluding that " $[t]$ he subsidiarity principle, which assumes the autonomy of the parts within the whole, does not ... seem to safeguard society from moving in either a collectivist or an individualist direction. It does not appear strong enough to resist purely pragmatic tendencies whether coming from above or from below."). 
individual self-realization through a rich and diverse "civil society"; nor yet can it be exhausted by application to legislative or democratic processes in the political sphere. ${ }^{41}$ It comprehends all of these, as separate aspects of a common good, the sum total of the conditions necessary for individual human flourishing. In this way subsidiarity can be regarded as a principle of distribution of the diverse social functions that together make up the common good. ${ }^{42}$

Obviously, any of these constituent parts of the idea of subsidiarity is backed by a much fuller body of thought. This summary does not do justice to the intellectual traditions to which they belong, nor to the ways in which they may be contestable, but it does suffice to begin to identify the deep affinities between the concept of subsidiarity and the idea of human rights.

\section{Subsidiarity and the Idea of Human Rights}

The correlation between subsidiarity and human rights is apparent even from a basic glance at the first constitutive documents of international human rights law, the Universal Declaration of Human Rights, the International Covenant on Economic, Social and Cultural Rights, and the International Covenant on Civil and Political Rights (collectively, the International Bill of Rights).

To begin with, individual human dignity constitutes the first cornerstone of the edifice of the human rights idea. ${ }^{43}$ The Universal Declaration begins by affirming that "recognition of the inherent dignity and of the equal and inalienable rights of all members of the human family is the foundation of freedom, justice and peace in the world." ${ }^{44}$ The identical language is repeated in the first preambular clause of each of the Covenants. ${ }^{45}$ Article 1 of the Universal Declaration continues this theme, affirming that "[a]ll human beings are born free and equal in dignity and rights." ${ }^{46}$ Dignity is seen here to be inherent. It exists prior to the state, and therefore independently of any action, grant, or recognition by the state. As it does in the idea of subsidiarity, dignity provides the root basis for valuing the individual human person in a way that antecedes, morally and ontologically, any form of human organization or association.

The inherent dignity of the individual, however, does not mean that he or she exists in isolated, existential loneliness. Instead, in the idea of human rights, as in the idea of subsidiarity, one finds a recognition of the socially situated person, a being whose nature is necessarily relational. This point is easier to overlook in the context of human rights than that of subsidiarity. The form of human rights discourse is strongly oriented toward the individual; the guarantees of human rights instruments are framed in terms of the rights due to each person as an individual human being, not by virtue of his or her status within a group. Moreover, the strongly individualistic preconceptions that modern westerners, especially Americans, bring to declarations of rights inclines them to read these declarations even more than

${ }^{41}$ See NeIl. MacCormick, Questioning SOVEREIGNTY: LAW, STATE, AND NATION IN THE EuropeAN COMmONWEALTH 151-55 (2000) (distinguishing "market subsidiarity," “communal subsidiarity," "rational legislative subsidiarity,"and "comprehensive subsidiarity"); $c f$. Pizzolato, supra note 18, at 501-04.

42 See Pizzolato, supra note 18, at 496.

${ }^{43}$ Cf. Mary ANn Glendon, A World Made New: Eleanor RoOsevelt and the Universal Declaration of HUMAN RIGHTS 174-75 (2001); Klaus Dicke, The Founding Function of Human Dignity in the Universal Declaration of Human Rights, in THE CONCEPT OF HUMAN DIGNITY IN HUMAN RIGHTS DISCOURSE 111 (David Kretzmer \& Eckart Klein eds., 2002); David Feldman, Human Dignity as a Legal Value—Part I, 1999 PuB. L. 682, 690; Oscar Schachter, Human Dignity as a Normative Concept, 77 AJlL 848 (1983).

${ }^{44}$ Universal Declaration of Human Rights, GA Res. 217A, Dec. 10, 1948, pmbl., UN GAOR, 3d Sess., pt. I, Res., at 71, UN Doc. A/810 (1948) [hereinafter UDHR].

${ }^{45}$ International Covenant on Economic, Social and Cultural Rights, Dec. 16, 1966, pmbl., 993 UNTS 3 [hereinafter ICESCR]; International Covenant on Civil and Political Rights, Dec. 16, 1966, pmbl., 999 UNTS 171 [hereinafter ICCPR].

${ }^{46}$ UDHR, supra note 44, Art. 1. 
is necessary with an eye toward the lonely rights bearer. ${ }^{47}$ Yet any fair reading of international human rights documents provides a much more complex picture. At the outset, the solidarity of the human family is as much a building block of the structure of human rights as is individual dignity. ${ }^{48}$ More specifically, each of the documents of the International Bill of Rights amply recognizes and protects many of the social dimensions of human life, including marriage and family; nationality; religious affiliation, association, and assembly; cultural life; organized labor; and education. ${ }^{49}$ In Michael Perry's words, "The documentary record simply will not support the claim that international human rights talk generally proceeds in a dialect that is individualistic ...." 50

Moreover, the rights and liberties of the International Bill of Rights also stress that human society amounts to more than simply the individual and her unmediated relationship to a single whole, the state. The communal aspects of human rights are directed toward the protection of a wide variety of intermediate bodies and associations, from the family to labor organizations to religious communities and political associations. The implicit vision of society contemplated by the International Bill of Rights, like that contained in the idea of subsidiarity, recognizes a rich variety of contexts for relationship and fulfillment in the pursuit of the diverse ends of a fully human life.

Those ultimate ends themselves, however, are not prescribed by the state. The freedoms contemplated by human rights instruments deliberately create an ordered space for the liberty to pursue a range of goods. In other words, the idea of human rights, just as much as the principle of subsidiarity, necessarily entails an affirmation of a degree of pluralism and diversity in society. Consider, for instance, the freedom of religious belief and worship: a person's authentic search for and adherence to the meaning of life and the cosmos is fundamental to human dignity, ${ }^{51}$ yet one's human right "to manifest his religion or belief in teaching, worship and observance" ${ }^{25}$ is independent of the object of belief and worship or the doctrines and practices of the believer. The norm recognizes and protects our capacity to pursue the good in question by a plurality of paths.

That recognition suggests that the respect for diversity within the idea of human rights is really a function of the value of liberty, of the freedom of individuals and communities to seek the goods necessary for a dignified human life. But the freedom at stake in the idea of human rights does not consist simply in the absence of coercive power; it is not merely a negative liberty, a freedom from interference. It is also a freedom to act, a freedom for realizing a good-in short, an affirmative freedom. This feature becomes most obvious in the canon of human rights when we consider a person's "economic, social and cultural rights indispensable for his dignity and the free development of his personality. ${ }^{53}$ Education, for example,

${ }^{47}$ See MARY ANn Glendon, Rights TALK: The Impoverishment OF POlitical, Discourse 47-75 (1991).

${ }^{48}$ UDHR, supra note 44, pmbl., Art. 1; ICESCR, supra note 45, pmbl.; ICCPR, supra note 45, pmbl.; cf. GLENDON, supra note 43, at 174-77 (discussing the basic ideas in the preamble to the Universal Declaration of Human Rights).

${ }^{49}$ See generally UDHR, supra note 44; ICESCR, supra note 45; ICCPR, supra note 45: on recognition of the family as the "natural and fundamental group unit of society" (UDHR Art. 16; ICESCR Art. 10; ICCPR Art. 23); on the right to a nationality (UDHR Art. 15; ICCPR Art. 24); on the right to marry (UDHR Art. 16; ICCPR Art. 23); on freedom to manifest one's religion or belief "in community with others" (UDHR Art. 18; ICCPR Art. 18); on freedom to exchange information (UDHR Art. 19; ICCPR Art. 19); on freedom to associate and assemble (UDHR Art. 20; ICCPR Art. 21); on the right to participate in the cultural life of the community (ICESCR Art. 15; ICCPR Art. 27); on the right to self-determination of all peoples (ICESCR Art. 1; ICCPR Art. 1); on the right to form and join trade unions (UDHR Art. 23; ICESCR Art. 8; ICCPR Art. 22); and on the liberty to establish and direct educational institutions (UDHR Art. 26; ICESCR Art. 13).

${ }^{50}$ Michael. J. Perry, The IdeA of Human Rights, Four INQUiries 53-54 (1998).

${ }^{51}$ See Luigi GiUSSANI, THE RELIGIOUS SENSE 56 (1997) ("The religious sense is reason's capacity to express its own profound nature in the ultimate question: it is the 'locus' of consciousness that a human being has regarding existence. Such an inevitable question is in every individual, in the way he looks at everything.").

${ }^{52}$ UDHR, supra note 44, Art. 18; ICCPR, supra note 45, Art. 18.

${ }^{59}$ UDHR, supra note 44, Art. 22. 
is seen to be necessary for "the full development of the human personality," 54 and the right to work and to just pay must be respected to ensure "an existence worthy of human dignity." 55 But the rights to both education and labor are realized in the human capacity to act affirmatively, not merely to be free from interference. Even more basically, no liberty is more indispensable to human existence than "the fundamental right of everyone to be free from hunger," ${ }^{\circ 6}$ but that is clearly a "freedom" that (in most cases) is concretized more by the existence of affirmative conditions than by the absence of coercion. Though less intuitively obvious, the same observation can be made even when we consider civil and political rights, like freedom of speech and assembly, that are expressed as restraints on the state. The moral responsibility of the state not to interfere with people's civil liberties conforms with an understanding that the freedom in question consists of a capacity to act in the realization of a good. ${ }^{57}$

The combination of positive and negative liberty in the idea of human rights is confirmed by the way that human rights law portrays the role of the state. With respect to human rights, state responsibilities are ambivalent in ways very similar to those that we saw in connection with the principle of subsidiarity. The classic liberal idea of rights and the majority of the rights articulated in the International Bill of Rights express restraints and limitations on the state. They define and protect spheres of noninterference, from physical integrity ${ }^{58}$ to speech ${ }^{59}$ and association. ${ }^{60}$ At the same time, the obligation that each state assumes through these instruments is the affirmative one of undertaking "to respect and to ensure to all individuals within its territory and subject to its jurisdiction the rights recognized." ${ }^{61}$ The obligations to respect and ensure, even with regard to the traditional "liberal" rights, can give rise to affirmative state obligations to intervene in order to see that the rights are realized. ${ }^{62}$ Even more pointed toward the positive actions of the state aimed at realizing human rights, the International Covenant on Economic, Social and Cultural Rights requires that each party to the treaty "undertake[] to take steps, individually and through international assistance and co-operation, . . . to the maximum of its available resources, with a view to achieving

${ }^{54}$ Id., Art. 26; ICESCR, supra note 45, Art. 13.

${ }^{55}$ UDHR, supra note 44, Art. 23.

${ }^{56}$ ICESCR, supra note 45, Art. 11.

${ }^{57}$ SeeJOHN H. GARVEY, WHAT ARE FREEDOMS FOR? (1996). Although approaching the question from a very different theoretical perspective, the work of Amartya Sen and Martha Nussbaum tying human rights to human capabilities supports the same conclusion regarding the positive dimensions of civil and political liberties. See generally THE QUALITY OF LIFE (Martha Nussbaum \& Amartya Sen eds., 1993).

${ }^{58}$ See, e.g., UDHR, supra note 44, Art. 3 (security of person), Art. 4 (prohibition against slavery), Art. 5 (prohibition against cruel, inhuman, or degrading treatment), Art. 13 (freedom of movement); ICESCR, supra note 45 , Art. 12 (right to highest attainable standard of physical and mental health); ICCPR, supra note 45, Art. 6 (right to life), Art. 7 (prohibition against cruel, inhuman, and degrading treatment), Art. 8 (prohibition against slavery), Art. 9 (security of person).

${ }^{59}$ See, e.g., UDHR, supra note 44, Art. 19; ICCPR, supra note 45, Art. 19.

${ }^{60}$ See, e.g., UDHR, supra note 44, Art. 20; ICCPR, supra note 45, Art. 22.

${ }^{61}$ ICCPR, supra note 45, Art. 2.

${ }^{62}$ For example, the Human Rights Committee, in its comment on the right to life in the International Covenant on Civil and Political Rights, has commented:

The expression "inherent right to life" cannot properly be understood in a restrictive manner, and the protection of this right requires that States adopt positive measures. In this connection, the Committee considers that it would be desirable for States parties to take all possible measures to reduce infant mortality and to increase life expectancy, especially in adopting measures to eliminate malnutrition and epidemics.

Human Rights Committee, General Comment No. 6(16), in Report of the Human Rights Committee, UN GAOR, 37th Sess., Supp. No. 40, Annex V, at 93, UN Doc. A/37/40 (1982). For availability online, see infra note 125. Although here I have limited the discussion to the International Bill of Rights, it is worth pointing out that the European Court of Human Rights has developed a broad jurisprudence of affirmative obligations regarding civil and political rights. In that Court's case law, affirmative state obligations have been recognized with respect to human rights as varied as the right to life, the right to respect for family and private life, and the right to a fair trial. For a good overview of the case law, see generally Pieter van Dijk, "Positive Obligations"Implied in the European Convention on Human Rights: Are the States Still "Masters" of the Convention? in THE ROLE OF THE NATION-STATE IN THE 2IST CENTURY 17 (Monique Castermans-Holleman et al. eds., 1998). 
progressively the full realization of the rights recognized in the present Covenant by all appropriate means, including particularly the adoption of legislative measures. ${ }^{.63}$ With respect to these rights, especially, both scholars and supervisory institutions have advanced an obligations-based approach that can specify with greater precision the various affirmative state responsibilities that the rights entail ${ }^{64}$ While the specifics may be debated, as a general matter the position of the state with respect to human rights is clearly dual: both to refrain from violating them and to take affirmative measures to ensure the appropriate conditions for realizing them. ${ }^{65}$ Thus, the canon of international human rights, like the idea of subsidiarity, combines intervention with noninterference.

Whether in restraint or in positive action, though, the roles that the state is obligated to assume with respect to human rights do not amount to the definition of a specific model of government or economy. The obligations leave the parties a great deal of room for a diversity of systems. Obviously, the obligations are incompatible with a government set on destroying rights and liberties-on systematically discriminating against minorities, for instance, or on suppressing all political dissent-as well as with a government so removed from the wellbeing of its people that it will not implement measures of any kind to help ensure their dignity and freedom. In between these extremes, the foundational documents of human rights do not prescribe means and models. ${ }^{66}$

Overall, human rights and subsidiarity can both be summarized as ideas that advance an understanding of the common good as based in the totality of conditions necessary for a full and flourishing human life. Their most basic premises closely parallel one another in understanding what that "common good" and "flourishing" require. What, then, does this similarity imply for international human rights law?

\section{SUBSIDIARITY AND FUNDAMENTAL RIGHTS IN THE EUROPEAN UNION}

Although the inquiry here focuses on the place of subsidiarity in international human rights law generally, looking first toward subsidiarity's role in the European Union, where both subsidiarity and human rights have developed as basic constitutional principles, can make the transition to the international context easier. It confirms that the abstract principle of subsidiarity can be translated into more tangible juridical doctrines, but more important it illustrates that even in its more concrete applications subsidiarity remains relevant to human rights above all because of its fundamental orientation toward the structural problems of unity and difference in a multinational context.

\footnotetext{
${ }^{63}$ ICESCR, supra note 45, Art. 2.

${ }^{64}$ For example, with respect to the right to adequate food, the Committee on Economic, Social and Cultural Rights has elaborated on the nature of the state's obligation as including "the obligations to respect, to protect, and to fulfill." Committee on Economic, Social and Cultural Rights, General Comment No. 12, para. 15, UN Doc. E/C.12/1999/5, available at<http://www.unhchr.ch/tbs/doc.nsf>; see also Philip Alston \& Gerard Quinn, The Nature and Scope of State Parties' Obligations Under the International Covenant on Economic, Social and Cultural Rights, 9 HUM. RTS. Q. 156 (1987).

${ }^{65}$ In fact, if one takes Article 28 of the Universal Declaration of Human Rights seriously, the affirmative responsibilities of states with respect to the realization of human rights should not be limited to their own citizens or territorial jurisdiction, but should extend to a duty of solidarity and cooperation with other states for the creation and maintenance of an international order in which human rights are realized. Although those obligations have not been developed very much at all in the literature and practice of human rights, in principle an emphasis on subsidiarity would strengthen them since subsidiarity does not draw any sharp distinctions between state and international society. See Asbjørn Eide, Atticle 28, in THE UnIVERSAL DEClaration OF HUMAN RIGHTS: A COMMON STANDARD OF ACHIEVEMENT 597 (Gudmundur Alfredsson \& Asbjørn Eide eds., 1999); cf. Ronald St. J. Macdonald, Solidarity in the Practice and Discourse of Public International Law, 8 PACE INT'L L. REv. 259 (1996) (discussing role of solidarity as an obligation of states in international law); Edward McWhinney, The Concept of Co-operation, in INTERNATIONAL LAW: ACHIEVEMENTS AND PROSPECTS 425 (Mohammed Bedjaoui ed., 1991) (exploring international cooperation as a legal obligation of states).

${ }^{66}$ The most specific example of human rights norms supporting defined forms or processes of governance can be found in work advocating an emerging right to democratic rule, which also happens to be one of the few normative contexts in which subsidiarity and human rights have been linked explicitly. See Shelton, supra note 7 .
} 


\section{Subsidiarity as a Constitutional Principle in the European Union}

Immediately after the Second World War, Germany's desire to undo the massive centralization of national socialism led to extensive study of the possible application of subsidiarity to all the different spheres of social life, and to the transposition of the principle from the discourse of social philosophy into law. ${ }^{67}$ It was not until more than twenty years later that the idea of subsidiarity was introduced into the discourse of European supranational politics. ${ }^{68}$ Throughout the 1970s and 1980s, the idea became increasingly visible and began to make its way into official European Community (EC) documents, ${ }^{69}$ with the particularly strong support of Jacques Delors while he was president of the European Commission. ${ }^{70}$ The principle finally found a central juridical place in the European Union in 1991, as part of the Treaty on European Union (TEU or Maastricht Treaty) ${ }^{71}$ The Maastricht Treaty first articulates one version of subsidiarity without invoking the word itself, stating in Article 1 that " $[t]$ his Treaty marks a new stage in the process of creating an ever closer union among the peoples of Europe, in which decisions are taken ... as closely as possible to the citizen." Article 2 then asserts the principle by name: "The objectives of the Union shall be achieved as provided in this Treaty . . . while respecting the principle of subsidiarity"; ${ }^{73}$ and Article 5 of the EC Treaty, in turn, contains the operative definition of the principle:

The Community shall act within the limits of the powers conferred upon it by this Treaty and of the objectives assigned to it therein.

In areas which do not fall within its exclusive competence, the Community shall take action, in accordance with the principle of subsidiarity, only if and insofar as the objectives of the proposed action cannot be sufficiently achieved by the Member States and can therefore, by reason of the scale or effects of the proposed action, be better achieved by the Community.

Any action by the Community shall not go beyond what is necessary to achieve the objectives of this Treaty. ${ }^{74}$

\footnotetext{
${ }^{67}$ Millon-Delsol, supra note 8, at 191, 210-16. Most obviously, subsidiarity inspired Article 72 of the Basic Law of the German Federal Republic, which governs the allocation of concurrent powers between the federal government and the Länder. GRUNDGESETZ [Constitution] Art. 72. The principle was thereafter applied much more broadly, however, throughout a variety of German legislation, especially on social issues, as well as within the Länders' local law. MILLON-DELSOL, supra, at 211-13. Millon-Delsol attributes subsidiarity's success in the social and political discourse of postwar Germany also to its ability to serve as a "central pivot" around which liberal, socialist, and corporatist ideas could turn and unite, as well as its ability to serve as a focal point for the dynamics of federalism. Id. at 191, 215. There is, naturally, an extensive German literature on subsidiarity, although unfortunately very little of it is available in translation. For many of the most frequently cited German works, see the extensive bibliographies in $i d$. at 229-32, and Endo, supra note 10, at 1973-1965.

${ }^{68}$ Its first use came from a German member of the European Commission, Ralf Dahrendorf, who in 1971 took aim in a newspaper editorial at what he perceived to be an excessively bureaucratized European Community (especially the European Community's common agricultural policy) by suggesting that Europe should "move away from the dogma of harmonization towards the principle of subsidiarity." Endo, supra note 10, at 2019.

${ }^{69}$ See, e.g., Single European Act, Feb. 17 \& 28, Art. 25, 1987 O.J. (L 169) 1 (this subsidiarity provision in the environmental area was repealed later, when the requirement fell within the broader scope of the Treaty of European Union's subsidiarity provision, now found in Article 5 of the consolidated EC Treaty); Draft Treaty Establishing the European Union, Art. 12, 1984 O.J. (C 77) 33; Article 12, L'Union européenne: Présentation du rapport de synthèse de M. Tindemans, BULL. CE 12/75, cited in Endo, supra note 10, at 2017.

${ }^{70}$ See Endo, supra note 10, at 2007-2004. Delors's ideas about subsidiarity were explicitly and pervasively personalist, influenced especially by the twentieth-century French intellectual Emmanuel Mounier. Id. at 2003-2001; $c f$. Emmanuel Mounier, Personalism (Philip Mairet trans., 1970).

${ }^{71}$ TREATY ON EUROPEAN UNION, Feb. 7, 1992, 1992 O.J. (C 191) [hereinafter TEU]. For much fuller accounts of the process by which subsidiarity came to be recognized in the TEU, see PATRIZIA DE PASQUALE, IL PRINCIPIO DI SUSSIDIARIETÀ NELI.A COMUNITÀ EUROPEA (2000); Endo, supra note 10.

${ }^{72}$ TEU, supra note 71, Art. 1 (consolidated version, 1997) (emphasis added).

${ }^{79}$ Id., Art. 2.

${ }^{7+}$ Treaty ESTablishing THe European Community, Nov. 10, 1997, Art. 5, 1997 O.J. (C 340$) 3$ [hereinafter EC TREATY]. In addition to this direct, formal incorporation of the principle of subsidiarity in to the Treaties, the TEU
} 
Of course, subsidiarity's introduction into the TEU did not result from a systematic and principled affirmation of human dignity and freedom so much as from cruder political postures and compromises. ${ }^{75}$ It was, especially, a response to the profound transformation in the balance of power between the Community and the member states in the period before conclusion of the Maastricht Treaty. ${ }^{76}$ A seemingly inexorable increase in the scope of Community action and influence, with a concomitant loss of political authority at the member state level, provoked a significant fear of excessive centralization. Amid these growing concerns about the incidence of supranational Europe upon national sovereignty, the concept of subsidiarity was introduced as the "word that can save [the] Maastricht [Treaty]."77 The principle of subsidiarity thus emerged from the creative tensions between the common whole and the constituent parts of the European Union. It was introduced into the EU constitutional structure as a way of addressing the persistent opposition between centralized harmonization and local control.

However, like any product of such an amorphous political concern, the articulation of the principle was ambiguous and uncertain, and it predictably generated a small industry by academic commentators on subsidiarity, who ranged from those that hailed the principle as the next great European juridical ideal, to those that derided the concept as essentially meaningless. ${ }^{78}$ But the initial weaknesses of the formulation did not result in the idea's desuetude. On the contrary, rather than being content with a vague statement of political aspiration, the member states sought to clarify, develop, and implement the principle through additional political efforts and declarations. ${ }^{79}$ The most significant post-Maastricht development came in 1996 when an intergovernmental conference reached agreement on a Protocol on the Application of the Principles of Subsidiarity and Proportionality, which was entered into in connection with the Treaty of Amsterdam and thereafter annexed to the EC Treaty. ${ }^{80}$

It is not necessary here to determine in detail specific applications of subsidiarity to the distribution of Community competences in the positive law of the European Union. More relevant to this discussion is the role of subsidiarity as a general principle and a more widely applicable idea. As Theodor Schilling has put it, "Taking subsidiarity seriously implies basically not to restrict the subsidiarity principle to the role of a rule, as embodied in [Article 5 of the EC Treaty], but to give it an additional dimension by holding that there exists, alongside this rule, a subsidiarity principle" that should be given a wide scope ${ }^{81}$ For Schilling, the principle "pervades the whole field of the relationship between Community and Member State competences," recognizing a certain Community law supremacy yet balancing it against national

indirectly acknowledged the importance of subsidiarity by emphasizing, in the context of each new substantive sphere of Community law, that the member states would continue to have primary responsibility over those areas.

${ }^{75}$ See Endo, supra note 10.

${ }^{76}$ Bermann, supra note 2, at 348 .

${ }^{77}$ Deborah Z. Cass, The Word That Saves Maastricht? The Principle of Subsidiarity and the Division of Powers Within the European Community, 29 COMMON MKT. L. REv. 1107, 1107 (1992).

${ }^{78}$ See Bermann, supra note 2, at 333.

${ }^{79}$ E.g., Interinstitutional Declaration on Democracy, Transparency and Subsidiarity, 26 E.C. BULL., No. 10, 1993 , at 118; Overall Approach to the Application by the Council of the Subsidiarity Principle and Article 3b of the Treaty on European Union, Conclusions of the Presidency, 25 E.C. Bull., No. 12, 1992, at 12.

${ }^{80}$ Protocol on the Application of the Principles of Subsidiarity and Proportionality, TREATYOF AMSTERDAM AMENDING THE TREATYON THE EUROPEAN UNION, THE TREATIES ESTABLISHING THE EUROPEAN COMMUNITIES AND CERTAIN RELATEd ACtS, Oct. 2, 1997, 1997 O.J. (C 340) 1, 105 [hereinafter Amsterdam Protocol]. The Amsterdam Protocol clarifies in several respects the scope and content of subsidiarity as a Treaty norm, but its most significant step was to shift subsidiarity to a more procedural level. Id., Arts. 4, 9-12. It may be noted that George Bermann argued in favor of this proceduralization of subsidiarity years before the Amsterdam Protocol made it a reality. See generally Bermann, supra note 2.

${ }^{81}$ Theodor Schilling, A New Dimension of Subsidiarity: Subsidiarity as a Rule and a Principle, 1994 Y.B. EUR. L. 203, 255. But see Reimer von Borries \& Malte Hauschild, Implementing the Subsidiarity Principle, 5 COLUM.J. EUR. L. 369, 369 (1999) (arguing that the principle of subsidiarity, "rather than being a socio-philosophical doctrine, is a principle of constitutional law. It . . . is simply a rule for the rational exercise of Community competencies. Article [5] contains no meaning other than this rule." (footnote omitted)). 
interests in the service of the overall coherence and stability of the Community. ${ }^{82}$ Gráinne de Búrca's assessment of the significance of subsidiarity confirms and amplifies Schilling's understanding. She points out that despite some dire assessments of its emptiness, the term "subsidiarity" has become increasingly deployed within the lawmaking and policy-setting activity of a wide range of actors and institutions within the European Union, giving the principle a broad practical significance ${ }^{83}$ Most of all, de Búrca understands the notion of subsidiarity in the Union to be a" "rhetorical device" that articulates and mediates basic, persistent problems of the relationship between the constituent parts of Europe and the whole:

Much of EU constitutional law has been taken up with the search for ways of resolving the tensions and balancing the interests of integration and differentiation, of harmonisation and diversity, of centralisation and localisation or devolution. The notion of subsidiarity can be seen as yet another conceptual space in which this balance can be negotiated, as a language through which the ongoing debate is channelled. ${ }^{84}$

Three points in connection with de Búrca's comments are of interest in exploring the relevance of subsidiarity to a broader international context. The first is to note how closely the tensions she identifies in the constitutional discourse of the European Union mirror the dichotomies inherent in the idea of subsidiarity, as described by Millon-Delsol earlier: liberty and unity, variety and commonality, intervention and noninterference. ${ }^{85}$ The role that subsidiarity plays in the European Union confirms the principle's more general character: it demarcates a conceptual territory in which unity and plurality interact, pull at one another, and seek reconciliation. The roots of the idea of subsidiarity and the roots of the human need for both belonging and differentiation reside in the same soil, and it would truly impoverish our discourse and reduce our capacity for understanding to limit subsidiarity to a technical European rule that does not grow up out of that ground.

Second, the way that subsidiarity works in the law, politics, and rhetoric of the European Union reveals that it operates as an alternative, and even in opposition, to the idea of sovereignty. It seeks to go beyond any fixed centralization of power and authority, and instead to accommodate the flexible, multilevel constitutional structure of the Union, in which there is not a single "sovereignty" but overlapping ones. As Ken Endo concluded in his discussion of the contrast between subsidiarity and sovereignty in the EU context, "More than anything, subsidiarity thus serves as a critical viewpoint with which to constantly undermine the internal and external foundations of . . State Sovereignty." 86

The third point that arises from de Búrca's observations is that, in important ways, the language of subsidiarity functions in the European Union exactly as the language of fundamental rights has been functioning there for an even longer period. They both serve as metaphors that channel into constitutional discourse a deeper dialogue about personhood, society, government, and state. The human rights law of the European Union has always been located at the intersection between common aspirations and national particularity. Arguments over

\footnotetext{
${ }^{82}$ Schilling, supra note 81 , at 255 . To accept subsidiarity as a legal principle with broader meaning and application than the rule of Article 5 does not necessarily mean that the way it is used in the European Union is as comprehensive as the idea I described in part I of this article, but the constitutional nuances are not of primary importance to the international legal context of this article. For further discussion of the possible divergences in uses and meanings of subsidiarity in the EU context, see MACCORMICK, supra note 41; Andreas Føllesdal, Survey Article: Subsidiarity, 6J.POL. PHIL. 190 (1998); Pizzolato, supra note 18 (speculating whether subsidiarity in the Union is "denatured" from its intellectual roots).

${ }^{83}$ Gráinne de Búrca, Reappraising Subsidiarity's Significance After Amsterdam (Harvard Jean Monnet Working Paper No. 7/99, 1999), at < http://www.jeanmonnetprogram.org/>.

${ }^{84} \mathrm{Id}$.

${ }^{85}$ See text at note 34 supra.

${ }^{86}$ Ken Endo, Subsidiarity $\mathcal{E}^{2}$ Its Enemies: To What Extent Is Sovereignty Contested in the Mixed Commonvealth of Europe? at 36 (EUI Working Papers No. RSC 2001/24, 2001), at <http://www.iue.it/RSCAS/WP-Texts/01_24.pdf>.
} 
fundamental rights in the Union, much like those regarding subsidiarity, are about the balance between the integrity of the whole and the autonomy and identity of the parts, a search for an equilibrium between unity and diversity that permits and encourages the emergence of a common European polity while still taking into account and respecting the basic values of national constitutional systems. ${ }^{87}$ Fundamental rights in the European Union are profoundly bound up with a struggle to define and maintain the "fundamental boundaries" of the different communities to which individuals belong, to use Joseph Weiler's terms, ${ }^{88}$ and subsidiarity represents the same tension.

\section{Subsidiarity in EU Fundamental Rights Law}

The Charter of Fundamental Rights of the European Union, adopted in December $2000,{ }^{89}$ is a paradigm of how subsidiarity and fundamental rights in the Union intersect with one another in their mutual preoccupation with the dynamic of unity and pluralism. In general, the Charter's text and context reflect two superficially contradictory, but deeply interconnected, aspects of European supranationalism: the commonality of Europe and the particularity of national and local identity. ${ }^{90}$ It presumes the value and existence of a significant degree of commonality among the "peoples of Europe" in whose name the Charter is offered, referring to a future "based on common values," invoking a common European "spiritual and moral heritage," and affirming the foundation of the Union in "the indivisible, universal values of human dignity, freedom, equality and solidarity." But just as it recognizes this harmonious unity of values, so the preamble also immediately bows to the diversity of "the peoples of Europe": "The Union contributes to the preservation and to the development of these common values while respecting the diversity of the cultures and traditions of the peoples of Europe as well as the national identities of the Member States and the organisation of their public authorities at national, regional and local levels ... ." ${ }^{\text {92 }}$ To use Weiler's evocative language, the Charter is "part of the iconography of European integration, contributing both to the identity [of] and identification with Europe" ${ }^{\prime 93}$ at the same time that it asserts and protects local identity out of a "deep modern and post-modern anxiety of European belongingness." ${ }^{94}$

The Charter's invocation of subsidiarity lies at the heart of this ambivalence. The preamble to the text "reaffirms, with due regard for the powers and tasks of the Community and the Union and the principle of subsidiarity," the rights articulated in the Charter ${ }^{95}$ Article 51 goes on to specify that " $[t]$ he provisions of this Charter are addressed to the institutions and bodies of the Union with due regard for the principle of subsidiarity." ${ }^{\text {" Be }}$ reminding us of the presence and claims of the plurality of member states, and the correlative limitations on the Union, subsidiarity moderates the unifying and monolithic pretensions of the

\footnotetext{
${ }^{87}$ See Paolo G. Carozza, The Charter and the Member States, in THE EuropeAn Union CharTER of FundamENTAL RIGHTS: CONTEXT AND POSSIBILITIES (Steve Peers \& Angela Ward eds., forthcoming 2003).

${ }^{88}$ JOSEPH H. H. WEILER, THE CONSTITUTION OF EUROPE, ch. 3 (2000).

${ }^{89}$ For an excellent account of the process by which the Charter was proposed, drawn up, and approved, see Gráinne de Búrca, The Drafting of the European Union Charter of Fundamental Rights, 26 EUR. L. REV. 126 (2001).

${ }^{90}$ On the general tension between the commonality of the Union and the particularity of the several member states that pervades the Charter, see Carozza, supra note 87.

${ }^{91}$ Charter, supra note 5, pmbl.

${ }^{92} I d$. Moving beyond the preamble, the Charter's substantive rights maintain this antinomy, providing, for example, that " $[t]$ he Union shall respect cultural, religious and linguistic diversity," while also guaranteeing the right of every EU citizen to "move and reside freely within the territory of the Member States." Id., Arts. 22, 45.

${ }^{93}$ Joseph H. H. Weiler, Human Rights, Constitutionalism and Integration: Iconography and Fetishism, 3 INT'L L.F. 227, $232(2001)$

${ }^{94}$ WEILER, supra note 88 , at 343.

${ }^{95}$ Charter, supra note 5 , pmbl.

${ }^{96}$ Id., Art. 51.
} 
Charter even while it asserts a fundamental unity of values. The principle of subsidiarity seems to be working here, in the context of fundamental rights, just as de Búrca described it in EU constitutional discourse generally, as a rhetorical mediator between the universal and the particular, integration and differentiation, harmonization and diversity. ${ }^{97}$

However, the more directly practical application of subsidiarity to the Charter is not at all obvious. So far, the Charter has not been taken up in any detail by the courts of the Union, and the scholarly commentary has paid scant attention to the question of subsidiarity in the document. More generally, in light of both the explicit linkage between subsidiarity and human rights in the Charter and the underlying similarities between fundamental rights discourse and subsidiarity in the European Union discussed earlier, it may be somewhat surprising that the two have only mildly and indirectly intersected in EU law. There are two basic reasons for this, one legislative and one judicial. To begin with, controversy has long been waged in European Union law over the extent to which the Union should be deemed to have any legislative competence over fundamental rights, and for now the contention has been resolved in practice in favor of the view that Community institutions do not have a basis for legislation in the area without an additional amendment to the EC Treaty. ${ }^{98}$ Therefore, to the extent that subsidiarity in the European Union is intended to control the Union's exercise of legislative authority, it does not apply to fundamental rights matters. ${ }^{99}$ Similarly, with respect to the European Court of Justice, the judicial use of subsidiarity has also been a contested point in academic commentary, ${ }^{100}$ and so far the ECJ has not applied the principle to itself with respect to its own exercises of judicial authority. Thus, the Court's fundamental rights jurisprudence has not benefited from any explicit consideration of the principle of subsidiarity.

There are nevertheless two ways that subsidiarity could be regarded as tacitly present in the case law of the European Court of Justice. One has to do with the sources of law that the ECJ uses in reaching decisions on the content of EU fundamental rights, and the other involves the scope of that law's application to the actions of member states. First, the Court's jurisprudence on general principles of fundamental rights has consistently relied on "the constitutional traditions of the Member States," including not just national constitutions but also more specific references to international treaties to which the member states are parties and more general invocations of the member states" "common heritage," "common values," and the like. ${ }^{101}$ The result is a potentially fruitful process of legal borrowing and a dialectic of judicial

\footnotetext{
${ }^{97}$ See supra text at note 84 .

${ }^{98}$ See Alston \& Weiler, supra note 6, at 22-27; Armin von Bogdandy, The European Union as a Human Rights Organization? Human Rights and the Core of the European Union, 37 COMmON MKT. L. REV. 1307 (2000).

${ }^{99}$ One could presumably argue that locating legislative competence over human rights matters exclusively in the member states and not in the Union is itself a manifestation of subsidiarity; this is one possible way of reading the Charter of Fundamental Rights when it proclaims both a respect for subsidiarity and an intent to maintain the existing allocation of competences in the Union. In reality, though, that would not be subsidiarity, which necessarily entails shared authority, so much as pure decentralization.

${ }^{100}$ After the adoption of the Maastricht Treaty, the issue was whether subsidiarity could be applied by the ECJ to other EC institutions. See, e.g., A. G. Toth, Is Subsidiarity Justiciable? 19 EUR. L.R. 268 (1994). More recently, the question has turned to the application of the principle by the ECJ to itself with regard to its own exercise of interpretive powers. For persuasive arguments in favor of a "judicial subsidiarity" in the Union, see Gráinne de Búrca, The Principle of Subsidiarity and the Court of Justice as an Institutional Actor, 36 J. COMMON MKT. STUD. 217 (1998); Edward T. Swaine, Subsidiarity and Self-Interest: Federalism at the European Court of Justice, 41 HARV. INT'L L.J. 1 (2000).

${ }^{101}$ See, e.g., Case 155/79, AM\&S Europe Ltd.v. Commission, 1982 ECR 1575; Case 44/79, Hauer, 1979 ECR 3727. One recent, post-Charter case that exemplifies this practice is the opinion of Advocate General Mischo in Booker Aquaculture Ltd., Cases C-20/00,C-64/00 (Sept. 20, 2001), available at <http://www.curia.eu.int/en/index.htm> (Court's decision pending). Mischo undertakes a brief survey of the scope of the right to private property in the constitutional law of several member states before turning to the Charter to reinforce the conclusion that would be drawn on the basis of national constitutional law, and then to the European Convention on Human Rights. While the interaction of the various sources here is relatively cursory, it still points the way toward continued exchange and cross-fertilization between the national and European legal orders.

With regard to the characteristics of fundamental rights as general principles of law in the EU more generally, including their reliance on national constitutional traditions, see TAKIS TRIDIMAS, THE GENERAL PRINCIPLES OF EC
} 
dialogue between the EU courts and the member states, especially their constitutional courts or the equivalent. ${ }^{102}$ The Court's turning to national constitutional traditions to justify the normative content of Community fundamental rights can be characterized in some sense as an example of subsidiarity at work. It is consistent with subsidiarity's emphasis on pluralism and the integrity of local associations to look to national constitutional law in assessing and fashioning EU fundamental rights norms. Taken collectively, the national constitutional traditions offer a breadth of experience and a depth of jurisprudence that could not be matched by the solitary work of the ECJ. Even individual constitutional courts acting alone may sometimes have advantages in adjudicating rights, because of their greater proximity to the EU citizen. ${ }^{103}$ Despite the position of the ECJ as the ultimate arbiter of the scope and content of fundamental rights in the Union, and despite the nature of its decisions as not necessarily reflecting any one rule or practice of national law, this approach still takes into account, incorporates, and synthesizes national approaches to the rights at issue. It respects the member states' institutions and traditions, and thus reflects one important application of subsidiarity to the EU law of fundamental rights.

A second instance of subsidiarity's implicit relevance to the ECJ's adjudication of fundamental rights involves the scope of its judicial review of member states' acts alleged to violate Community fundamental rights. ${ }^{104}$ The case law of the Court shows in practice a sort of sliding scale of review for compliance with norms of Community fundamental rights. At one end, the Court exercises the strongest central control and supervision when it is reviewing the acts of Community institutions and thus where national law and institutions are not (directly, at least) at issue. ${ }^{105}$ When reviewing instead a member state's act that implements Community rules through national law, the ECJ recognizes a certain degree of latitude for national legal institutions in assessing the constraints on that law imposed by the Community's fundamental rights principles. ${ }^{106}$ Finally, when reviewing a member state's act that does not implement a Community norm but, instead, restricts or derogates from the EC Treaty's basic obligations (relying on a stated ground of exception in the EC Treaty itself to do so), the ECJ permits the greatest latitude to national courts, sometimes presenting its own role merely as one of providing information and criteria needed for the national court alone to decide on the application of Community fundamental rights law to the act at issue. ${ }^{107}$

This gradated scope of review can be considered consistent with the requirements of the principle of subsidiarity. In circumstances where the European Court of Justice is reviewing the acts of another EU institution, the ECJ itself is the institution most suited to the definitive appraisal of such measures, as the Court is not dealing with a member state's act at all but with a Union measure that has effect in all of the states, making the need for uniformity of interpretation at the EU level self-evident. Where acts of member states' institutions are

LAw 202-43 (1999); A. G. Toth, Human Rights as General Principles of Law, in the Past and in the Future, in GENERAL PRINCIPLES OF EUROPEAN COMMUNITY LAW 73 (Ulf Bernitz \& Joakim Nergelius eds., 2000).

${ }^{102}$ See, e.g., TRIDimas, supra note 101, at 16. Regarding the judicial dialogue between the ECJ and national courts both in this respect and more generally, see THE EUROPEAN COURT AND NATIONAL COURTS-DOCTRINE ANDJURISPRUDENCE (Anne-Marie Slaughter et al. eds., 1998).

${ }^{103}$ I am not suggesting that subsidiarity leads to any hard rule or method of interpretation by the ECJ. The sort of comparative exercise in fundamental rights that subsidiarity encourages could not result in any mechanical formula for the recognition, understanding, or justification of the rights in question but, rather, serves (at its best) as a source of perspective and critical distance in fashioning a balanced and open jurisprudence of rights. See Paolo G. Carozza, Uses and Misuses of Comparative Law in International Human Rights: Some Reflections on the Jurisprudence of the European Court of Justice, 73 NOTRE DAME L. REV. 1217 (1998).

${ }^{104}$ For a general overview of the structure of, and justification for, the several kinds of review, see WEILER, supra note 88 .

${ }^{105}$ See, e.g., Hauer, 1979 ECR 3727, para. 14.

${ }^{106}$ See, e.g., Case 5/88, Wachauf, 1989 ECR 2609, paras. 18-19.

${ }^{107}$ See, e.g., Case C-368/95, Familiapress, 1997 ECR I-3689; Case C-299/95, Kremzow, 1997 ECR I-2629, para. 15 ; Judgment of 18 June 1991, ERT, 1991 ECR I-2925. 
subjected to ECJ review for compliance with Community fundamental rights law, subsidiarity does not urge as strongly that the ECJ be the single judicial voice determining the interpretation and application of the norms. ${ }^{108}$ Interpretation of the scope and meaning of fundamental rights requirements by national courts enhances the possibility of fitting the EU law as much as possible into the existing context of legal and political traditions of the member state. ${ }^{109}$ In the case of a national law derogating from the EC Treaty, a common Union norm is still present but even more indirectly, and the member state's measure is often even more firmly linked to strong national needs, values, and traditions (because by definition these are the sorts of measures that can justify a derogation). Subsidiarity then supports according an even greater degree of local interpretive discretion regarding the implicated fundamental rights norms.

In sum, a certain degree of subsidiarity is implicitly reflected in the existing fundamental rights law of the European Union. It must be emphasized, nevertheless, that this is only a very partially developed application of the principle. Limited to the judicial sphere, it largely takes the negative form of subsidiarity, emphasizing primarily the restraint of the supranational court and the devolution of interpretive authority. The only hint of the more affirmative aspects of assistance and intervention lies in the ECJ's language suggesting that the Court's role is to provide the information and criteria that will assist the national court in applying the Community fundamental rights norms to national law.

The continued development of the principle of subsidiarity in the context of the fundamental rights law of the European Union will depend at least in part on the shape that the Union takes after its next round of constitutional reforms, which will include discussions of the status of the Charter of Fundamental Rights. ${ }^{110}$ From the perspective of international human rights law, however, it is a development to be watched and hoped for. The Union could serve as a greenhouse for the grafting of the ideas of subsidiarity and human rights through practical experience and systematic reflection, yielding fruit for international law. That presumes, of course, that the law of the European Union is more than just one idiosyncratic instance where human rights and subsidiarity have happened to come into proximity-that subsidiarity, in other words, is as central and important to international human rights law as it is to the constitutional structure of the European Union.

\section{SUBSIDIARITY AND HUMAN RIGHTS IN INTERNATIONAL LAW}

\section{The Applicability of Subsidiarity to International Human Rights Generally}

In general, moving from the legal order of the European Union to international law can be problematic, since the Union is in so many respects a constitutional system and not a construct governed by classical principles of international law. ${ }^{111}$ But on the question of human

\footnotetext{
${ }^{108}$ Predictably, the Court's review of action by the member states is generally what provokes concern about the potential expansion of the scope of EU fundamental rights law, and about a concomitant reduction in those states' autonomy and local discretion. See Leonard Besselink, The Member States, the National Constitutions and the Scope of the Charter, 8 MAASTRICHT J. EuR. COMP. L. 68 (2001); von Bogdandy, supra note 98.

${ }^{109}$ Compare Amsterdam Protocol, supra note 80, Art. 7, which provides:

Community measures should leave as much scope for national decision as possible, consistent with securing the aim of the measure and observing the requirements of the Treaty. While respecting Community law, care should be taken to respect well established national arrangements and the organisation and working of Member States' legal systems.

${ }^{110}$ Although the Charter was adopted as a mere declaration of principles rather than as a formally binding legal instrument (e.g., a separate treaty or an amendment to the existing treaties), its status has officially been made part of the current process of considering the future constitutional structure of the Union. See Laeken Summit Declaration on the Future of the Union, para. 23(5), 2001 O.J. (C 80/85) 23.

"' See, for example, the debate between Theodor Schilling, The Autonomy of the Community Legal Order-An Analysis of Possible Foundations, 37 HARV. INT'LL.J. 389 (1996), and Joseph H. H. Weiler, The Autonomy of the Community Legal Order: Through the Looking Glass, in WEILER, supra note 88, at 286.
} 
rights and subsidiarity, it is exactly the Union's legal and political position at the intersection of constitutional and international law that can make it an especially interesting and useful example to consider. As a result of that suigenerisstatus, the European Union has developed unparalleled relationships between national and supranational norms, actors, and institutions, and it is constantly pulled taut between the commonality of integration and the particularity of separate national units. The same tension also characterizes many of the most persistent challenges of international human rights law, and it virtually defines the field of application of subsidiarity as well. Thus, the very singularity of the Union, rather than making it an incomparable example, gives.it the possibility of contributing to the larger question before us.

But as we move from EU to international legal order, one threshold question within the terms of the principle of subsidiarity itself is whether it relates to international order at all or instead applies only within political communities that enjoy some sort of independent or sovereign status. To the extent that we might regard subsidiarity as fundamentally concerned with the distribution of competences among different levels of governance, this is a legitimate question. In that case, without some sort of constitutional order, there would be no sovereign authority to "divide up," as it were. In the first part of this article, however, I emphasized the comprehensive reach of subsidiarity, flowing from its grounding in a notion of the common good as the totality of conditions necessary for the flourishing of every individual in society. Subsidiarity is applicable whenever a community cannot be said to be capable of achieving that common good in a self-sufficient manner. If a political community is capable of being a complete or perfect community, encompassing the sum total of the requirements for the common good, then it has no need for the subsidium of any larger human association, and subsidiarity could be considered inapplicable.

Such a "perfect" community can probably exist only as an ethical ideal and not as an empirical or juridical reality. ${ }^{112}$ But even if we did believe that in certain hypothetical, concrete circumstances the conditions for a completely self-sufficient human community could be met, it should be obvious that in our contemporary world no community is capable of attaining the complete good of its members without international interaction and cooperation: "National states cannot even take care of their own common good in isolation in this new era; much less can they handle the problems of the universal common good. . . It is precisely the 'insufficiency' in the moral and political sphere which is today the mark of the nationstates." 119 To the extent that this proposition is true, subsidiarity not only gains some applicability, but in fact requires that international order be directed toward helping smaller communities achieve their ends. Applying the principle of subsidiarity to the international community, as with any other level of human association, would generate a responsibility for that order to intervene and assist, but would prohibit it from taking over what more local communities can accomplish by themselves. ${ }^{114}$

When we apply that idea not just to international order generally, but specifically to international human rights, the broad formulation of the principle is relatively straightforward. Subsidiarity requires, first, that local communities be left to protect and respect the human dignity and freedom represented by the idea of human rights whenever they are able to achieve those ends on their own; in many cases, this aspect of subsidiarity will result in a degree of

112 See Kossel, supra note 21, at 44.

${ }^{113}$ Id. at 45; cf. Pizzolato, supra note 18, at 507 (arguing that inadequacy of the nation-state justifies supranational authority). In this vein, FINNIS, supra note 27 , at 149-50, also states:

If it now appears that the good of individuals can only be fully secured and realized in the context of international community, we must conclude that the claim of the national state to be a complete community is unwarranted and the postulate of the national legal order, that it is supreme and comprehensive and an exclusive source of legal obligation, is increasingly what lawyers would call a "legal fiction".

${ }^{114}$ Cf. Robert P. George, Natural Law and International Order, in INTERNATIONALSOCIETY 54, 64-66 (David R. Mapel \&Terry Nardin eds., 1998) (arguing that the natural law tradition envisages a world government of limited scope). 
discretion over the interpretation and implementation of rights like that seen in the case law of the European Court of Justice. Second, subsidiarity supports the integration of local and supranational interpretation and implementation into a single community of discourse with respect to the common good that the idea of human rights represents. And third, to the extent that local bodies cannot accomplish the ends of human rights without assistance, the larger communities of international society have a responsibility to intervene. Insofar as possible, however, the subsidium of the larger community should be oriented toward helping the smaller one achieve its goal without supplanting or usurping the latter society's freedom to pursue its own legitimate purposes.

As applied to specific problems and issues in human rights, that summary of the principle of subsidiarity is too packed with the need for the exercise of practical reason to allow any mechanical set of consequential rules to flow from it. ${ }^{115}$ But even when the principle is stated in such general terms, its import can be weighed. One of the first observations we can make is that subsidiarity does not express fundamentally new ways of ordering the international human rights system. It does use a somewhat different vocabulary, makes disparate features of the system more coherent with one another, and stresses certain aspects more than others, but overall it describes much of the way that the law of international human rights has been structured since its inception.

One of the first features of international human rights law that one confronts as a student is its penetration into domestic law in ways that subvert, or at least ignore, some of the central structural concepts of classic international law, such as sovereignty, territoriality, and domestic jurisdiction. As any basic, mainstream introduction to the subject would tend to emphasize, the central innovation of human rights law within international law was the idea that a state's treatment of its own citizens is a matter of international concern, a basic value of the international community. ${ }^{116}$ Accordingly, international norms, backed by institutions, supplant the autonomy of states where human rights are concerned. Subsidiarity preserves and reinforces that perspective, because it presumes a single common good that can be most fully realized only in a global community. Thus, the principle does not reconstitute the sovereign state as the object of its concern. It explicitly contemplates intervention and assistance for the purpose of protecting human dignity. State sovereignty is therefore subsidiarity's principal conceptual competitor, ${ }^{117}$ a point that I will explore in more detail below. First, though, I want to take up a different, almost opposite, way that subsidiarity reflects existing structures of international human rights law.

As soon as the novice student of human rights learns that in the twentieth century international norms and institutions swept away the formal, positivistic obstacles of sovereignty, she almost simultaneously begins to observe features of the discipline that oddly seem to contradict the first lesson. Before long, it becomes evident that since its formal birth after 1945 and continuing to the present, international human rights law has been characterized by a certain normative thinness-an incapacity to specify in sufficiently determinate ways the content of its requirements-and by mechanisms of supervision and compliance that leave great latitude to states to implement and enforce the norms as they see fit.

The first characteristic, the lack of a thick normative content, has been identified by Philip Alston as one of the ways in which international human rights law is still "immature."118 The

\footnotetext{
${ }^{115}$ Cf. id. at 65-66 (noting that "the application of the principle of subsidiarity is more a matter of art than of science" and that it cannot be "applied mechanically or with anything approaching mathematical precision").

${ }^{116}$ See, e.g., Louis Henkin, International Law: Politics, Values and Functions, 216 RECUEIL DEs Cours 208-26 (1989 IV).

${ }^{117} \mathrm{Cf}$. Endo, supra note 86 (identifying sovereignty as the "principal opponent concept" of subsidiarity).

${ }^{118}$ Philip Alston, Introduction to Human RighTS LAW at xi, xii (Philip Alston ed., International Library of Essays in Law and Legal Theory, 1996). Alston is responding to the much deeper critique that Marti Koskenniemi and other postmodern theorists have leveled against human rights as being not only "immature" but basically incoherent, because they are irretrievably indeterminate. I am well aware of that critique of rights, and agree that it is a powerful challenge to facile assertions of a false (and potentially colonialist) "universality" of values. Certainly, if
} 
content of human rights norms has moved toward greater specificity and concreteness in the short life span of international human rights, but even today one of the most obvious features of human rights law is the openness and indeterminacy of its norms. It is characteristic of the primary legal instruments themselves, as well as the associated doctrines, practices, and political rhetoric surrounding international human rights.

The framers of the Universal Declaration of Human Rights in 1948 considered the generality of its provisions necessary to achieving the consensus of the diverse set of states assembled. ${ }^{119}$ Perhaps some hoped that over time, with the knowledge and use of the Declaration, greater articulation of and agreement about the content of human rights norms would emerge. In fact, the development of human rights law since then can be described as a progressive movement toward greater normative specificity, beginning with the more detailed presentation of the Universal Declaration's provisions in the International Covenant on Economic, Social and Cultural Rights ${ }^{120}$ and the International Covenant on Civil and Political Rights. ${ }^{121}$ Subsequent conventions and treaty regimes, such as those on the elimination of racial discrimination ${ }^{122}$ and discrimination against women, ${ }^{123}$ in large part continued to give more definition to the prior, more open and abstract norms of the Universal Declaration and the Covenants. Beyond the primary legal instruments themselves, the institutions of international human rights have worked diligently to continue the process of norm specification, both through the application of the standards to specific cases and through the general interpretation of treaty provisions. For instance, pursuant to the International Covenant on Civil and Political Rights, the Human Rights Committee issues "General Comments" giving more specific content to such abstract norms as the right to life, ${ }^{124}$ and at the same time it develops normative specificity through its adjudication of violations of the Covenant in connection with specific individual petitions. ${ }^{125}$ Comparable development of the norms has occurred through other human rights treaty regimes. ${ }^{126}$ At the level of regional human rights, the process of norm specification has been even more pronounced, as rich and sophisticated bodies of jurisprudence have emerged from the European and inter-American systems. ${ }^{127}$

it is accepted in its entirety, then my project here is basically futile. Ultimately, however, it should be clear that the premises of my argument do accept as given that it is possible to engage in a meaningful inquiry into a communicable "common good" and a knowable "human dignity." I do not, therefore, take on directly the postmodern rights critique. Recognizing that these concepts and their political uses are subject to our historically contingent and often frail human judgments does not, in my view, require abandonment of the rights project so much as a constant willingness to engage in critical self-reflection about our uses of the language of rights. If I am right, the relationship of subsidiarity to human rights that I take up here is one way to keep a measure of distance between the virtues of rights talk and its hegemonic tendencies, a way to use the language of rights without its being the Trojan horse of a narrowly circumscribed liberal Western ideology.

${ }^{119}$ See generally GLENDON, supra note 43.

${ }^{120}$ ICESCR, supra note 45.

${ }^{121}$ ICCPR, supra note 45.

${ }^{122}$ International Convention on the Elimination of All Forms of Racial Discrimination, opened for signature Mar. 7 , 1966, 660 UNTS 195.

${ }^{123}$ Convention on the Elimination of All Forms of Discrimination Against Women, opened for signature Mar. 1, 1980, 1249 UNTS 13.

${ }^{124}$ Human Rights Committee, General Comment No. 3, UN Doc. CCPR/C/21/Rev.1/Add.1 (1981). For availability online, see note 125 infra.

${ }^{125}$ For a survey of the jurisprudence of the Human Rights Committee, see SARAH JOSEPH, JENNY SCHULTZ, \&

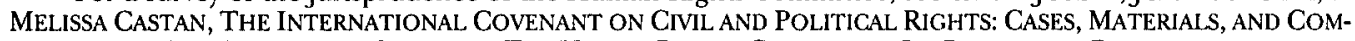
MENTARY (2000); DOMINIC MCGOLDRICK, THE HUMAN RIGHTS COMMITTEE: ITS ROLE IN THE DEVELOPMENT OF THE INTERNATIONAL COVENANT ON CIVIL AND POLTICAL RIGHTS (1994). Easy access to the text of the decisions and views of the Human Rights Committee can be found at <http://www.unhchr.ch/tbs/doc.nsf $\rangle,\langle$ http: $/ /$ www $1 . u m n . e d u /$ humanrts/undocs/undocs-index.html $>$.

${ }^{126}$ See, e.g., THE UNited NATIONS AND Human Rights (Philip Alston ed., 1992) (providing general overview of $\mathrm{UN}$ human rights treaty regimes).

${ }^{127}$ For the jurisprudence of the European Court of Human Rights, the cases are digested by article number in

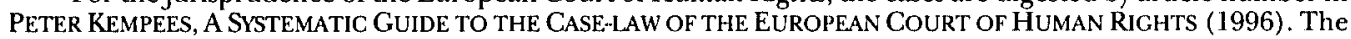
full texts of the cases are found in European Court of Human Rights, Reports of Judgments and Decisions, Series A, and at <http://www.echr.coe.int/Eng/Judgments.htm >. For the jurisprudence of the Inter-American Court of Human Rights, see the Court's Web site at <http://www.corteidh.or.cr/index-ingles.html $>$. 
In light of this story of progressive development of the normative dimensions of human rights, it is all the more striking that normative openness and underdetermination remains one of the most apparent features of international human rights law. Despite the multiplication of legal instruments, ambiguity still characterizes some of the most fundamental terms. Consider, for example, the most recent of the universal human rights treaties, the Convention on the Rights of the Child. ${ }^{128}$ While its provisions are much more detailed and comprehensive than the earlier and more generic protections in the International Covenant on Civil and Political Rights, it still relies throughout on the concept of "the best interests of the child." ${ }^{29}$ Yet this term, in the abstract, is so vague that its meaning effectively varies widely across the cultural, legal, and political contexts in which it may be applied. ${ }^{130}$ Similarly, the interpretive efforts of international institutions like the Human Rights Committee, while adding to the understanding of some of the basic norms, cannot ordinarily impose their interpretations of the treaties on the states party to them. ${ }^{131}$ Thus, the relatively open meaning of the basic norms of international human rights law leaves a great deal of interpretive latitude to states.

Various practices and doctrines of international law generally and of human rights in particular reinforce this interpretive latitude. One particularly contentious area has been the set of legal rules regarding the uses of reservations and declarations with respect to human rights treaties. The genesis of the current law regarding reservations to multilateral treaties is fairly well known to international lawyers. ${ }^{132}$ As the International Court of Justice stated in its 1951 case on the Genocide Convention, reservations are permissible except to the extent that they are prohibited by the terms of the treaty itself or are contrary to its object and purpose. ${ }^{133}$ Moreover, one of the objects of the Genocide Convention was to secure as widespread an agreement as possible. ${ }^{194}$ Thus, allowing reservations actually furthered the object and purpose of the Convention because they enabled a greater number of states to accept the instrument. States could tailor the details of the norms to their particular needs, and in doing so would accept the central legal obligation of the treaty. The reservations arrangement announced by the ICJ (and later codified in the Vienna Convention on the Law of Treaties ${ }^{135}$ ) thus goes further than just making reservations permissible in the case of multilateral human rights treaties: it makes a certain amount of state discretion over the treaty norms central to the universal aspirations of that treaty. It derives the necessity for interpretive pluralism directly from the core purposes of the treaty.

Since the Reservations to the Genocide Convention case, the practice of attaching reservations and declarations to human rights treaties has grown increasingly controversial, as some states have used the power to escape some of the most basic norms-most obviously in the case of the Convention on the Elimination of All Forms of Discrimination Against Women, where some states have emptied their obligations of all content by ratifying the treaty subject to

${ }^{128}$ Convention on the Rights of the Child, Nov. 20, 1989, 1577 UNTS 3.

${ }^{129}$ Id., Arts. 9, 18, 37.

${ }^{190}$ See, e.g., ThE BeSt INTERESTS OF THE CHILd: RECONCILING CULTURE ANd Human Rights (Philip Alston ed., 1994).

${ }^{131}$ See, for example, the exchange between the Human Rights Committee and the United States and the United Kingdom regarding the compatibility of reservations with the object and purpose of the ICCPR. Human Rights Committee, General Comment No. 24, UN Doc. CCPR/C/21/Rev.1/Add.6 (1994), reprinted in 34 ILM 839, 843 (1995); Observations on General Comment No. 24(52), United States of America, in Report of the Human Rights Committee, UN GAOR, 50th Sess., Supp. No. 40, Vol. I, Annex V, at 422, UN Doc. A/50/40 (1995), reprinted in 16 HuM. RTS. L.J. 52, 53 (1995); Observations on General Comment No. 24(52), United Kingdom of Great Britain and Northern Ireland, id. at 424, reprinted in 16 HuM. RTS. L.J. at 52.

${ }_{132}$ See, e.g., Alain Pellet, Second Report on Reservations to Treaties, UN Doc. A/CN.4/477 \& Add.1 (1996)

${ }^{193}$ Reservations to the Convention on the Prevention and Punishment of the Crime of Genocide, Advisory Opinion, 1951 ICJ REP. 15, 29 (May 28).

${ }^{134} I d$. at 24.

${ }^{135}$ Vienna Convention on the Law of Treaties, opened for signature May 23, 1969, Arts. 20-23, 1155 UNTS 331. 
comprehensive reservations. ${ }^{136}$ The United States has made a practice of using reservations and declarations fairly extensively to tailor its treaty obligations to the current state of its domestic law, provoking a pointed exchange with the Human Rights Committee over who commands the interpretive authority to determine whether a reservation is compatible with the object and purpose of the treaty. ${ }^{137}$ Setting aside the merits of the U.S. reservations, the relevant point here is that the current doctrines and practices of reservations to human rights treaties do effectively increase the interpretive discretion of states even beyond the openended language of the treaty norms themselves.

The same can be said of limitations and derogations clauses within human rights treaties. Treaty provisions like "[e]veryone shall have the right to freedom of association with others"138 are already extremely broad and indeterminate as applied to complex, concrete circumstances. They become even more subject to a pluralism of interpretation when followed by the recognition that the rights may be restricted by states as "necessary in a democratic society in the interests of national security or public safety, public order (ordre public), the protection of public health or morals or the protection of the rights and freedom of others." 139 As the European Court of Human Rights has recognized in its application of the limitations clauses of the European Convention on the Protection of Human Rights and Fundamental Freedoms, the questions raised by such provisions-e.g., public morals, national securityare especially appropriate for the granting of greater deference to local authorities. ${ }^{140}$

In those cases, the ECHR has expressed the degree of latitude it is prepared to accord by invoking the "margin of appreciation," the Court's judicially created doctrine of self-restraint, which refers to the breadth of deference or error the Court will allow national bodies before it will declare a violation of one of the substantive guarantees under the Convention. ${ }^{141}$ The idea of the margin of appreciation, however, is applied much more broadly than just in limitation and derogation cases. Considered by some to be the cornerstone of the Convention's respect for the diversity of the nations within the Council of Europe's human rights system, ${ }^{142}$ the margin of appreciation has continued to be used in a broad range of human rights cases. Recent ECHR decisions where the doctrine has figured importantly deal with issues as varied as discrimination against homosexuals in the armed services, ${ }^{143}$ parental leave allowance, ${ }^{144}$

${ }^{196}$ William A. Schabas, Reservations to the Convention on the Elimination of All Forms of Discrimination Against Women and the Convention on the Rights of the Child, 3 WM. \& MARY J. WOMEN \& L. 79 (1997).

${ }^{137}$ See sources cited supra note 131.

${ }^{138}$ ICCPR, supra note 45, Art. 22(1).

${ }^{139}$ Id., Art. 22(2).

${ }^{140}$ Classic cases in this regard include, for example, Handyside v. United Kingdom, 24 Eur. Ct. H.R. (ser. A) (1976) (recognizing limitations on obscenity based on the requirements of public morality), and Engel and Others, 22 Eur. Ct. H.R. (ser. A) (1976) (allowing limitations on discriminatory treatment in the punishment of military servicemen based on the need for military discipline). More recently, the ECHR has found limitations permissible in cases involving, for instance, restrictions on the right to home and family life based on the need for environmental planning. Chapman v. United Kingdom, 33 Eur. H.R. Rep. 399 (2001). See generally Eva BREMS, HUMAN RIGHTS: UNIVERSALITY AND DIVERSITY 365-90 (2001). For the Convention, see infra note 151.

${ }^{141}$ A recent and complete discussion of the use of the margin of appreciation doctrine, analyzing much of the ECHR case law in the context of a broad discussion of "legal techniques for the accommodation of diversity," can be found in BREMS, supra note 140, at 357-422, while a good, concise monograph surveying its use can be found in STEVEN GREER, THE MARGIN OF APPRECIATION: INTERPRETATION AND DISCRETION UNDER THE EUROPEAN CONVENTIONON HUMAN RIGHTS (2000). Earlier studies of note in the extensive body of literature regarding the margin of appreciation include ELIAS KASTANAS, UNITÉ ET DIVERSITÉ: NOTIONS AUTONOMES ET MARGE D'APPRÉCIATION DES ETATS DANS LA JURISPRUDENCE DE LA COUR EUROPÉENNE DES DROITS DE L'HOMME (1996); HOWARD CHARLES YOUROW, THE MARGIN OF APPRECIATION DOCTRINE. IN THE DYNAMICS OF EUROPEAN HUMAN RIGHTS JURISPRUDENCE (1996); Ronald St. J. Macdonald, The Margin of Appreciation, in THE EUROPEAN SYSTEM FOR THE PROTECTION OF HumAN RIGHTS 63 (Ronald St. J. Macdonald et al. eds., 1993). See also the collection of short articles by various authors in 19 HUM. RTS. L.J. 1-36 (1998).

142 See generally KASTANAS, supra note 141; Paul Mahoney, Marvellous Richness of Diversity or Invidious Cultural Relativism? 19 HUM. RTS. L.J. 1 (1998).

${ }^{143}$ Smith \& Grady v. United Kingdom, 1999-VI Eur. Ct. H.R. 45.

${ }^{144}$ Petrovic v. Austria, 33 Eur. H.R. Rep. 307 (2001). 
and assisted suicide. ${ }^{145}$ In fact, the ubiquity of arguments regarding the scope of the margin of appreciation makes it an especially clear example of the structural incorporation of local discretion into the legal doctrines of international human rights.

Outside formal legal doctrine, arguments over the appropriate degree of leeway in interpretation to be given to states often get expressed through the more overtly political rhetoric of cultural particularity, or relativism. Even as the official discourse of human rights has made great efforts to affirm the universality of rights, ${ }^{146}$ we continue to see an ongoing, and even intensified, debate over the legitimacy of singular universal human rights constructs in a plurality of cultural contexts. ${ }^{147}$ Again, at this point I am not concerned with the validity of the various arguments for culturally specific understandings of human rights. More generally than that, the persistence of assertions of culturally specific approaches to rights reveals that the basic language in which we are articulating the ethical imperatives of human rights remains to a fairly high degree indeterminate and open. It would be far less plausible to advance many of the arguments in favor of culturally specific human rights norms if such norms were more fully and precisely specified.

In short, despite all of the normative developments of international human rights law over the last half century, it is still characterized less by a fully articulated normative content than by the interpretive discretion that it leaves to states through the open-ended nature of its language, the legal doctrines supporting it, and the political context of the culturally pluralistic world to which it is intended to apply.

A parallel observation can be made about the practical implementation of human rights. Like its normative content, the institutional supervision and enforcement of international human rights law is notable mostly for the extent that it still relies so heavily on states' discretion regarding the degree and manner of implementation of human rights domestically. Just as, in most contexts, there are no definitive international interpreters of the normative content of human rights, ${ }^{148}$ so are there no international institutional authorities to mandate their implementation and enforcement. Instead, states remain the primary authorities responsible for human rights within their jurisdictions. This is not simply a question of "domestic jurisdiction," whose scope is now no longer significant. Other basic features of human rights law serve to place the states themselves in the position of principal avenues of implementation and enforcement. Many of the provisions of human rights treaties are by their nature dependent on the particularities of domestic legal norms and institutions, like the requirements for a criminally accused person to have a "fair and public hearing by a competent, independent and impartial tribunal established by law," 149 or they depend on national assessments like the "available resources" for allocation to the progressive realization of economic rights. ${ }^{150}$ Where violations do occur, rules regarding the exhaustion of remedies ensure that states will remain the primary recourse. ${ }^{151}$ And those domestic proceedings and determinations open up a wide range of possibilities for the precise role of international norms;

\footnotetext{
${ }^{145}$ Pretty v. United Kingdom, 35 Eur. H.R. Rep. 1 (2002).

${ }^{146}$ See, e.g., United Nations World Conference on Human Rights, Vienna Declaration and Programme of Action, UN Doc. A/CONF.157/24 (1993), reprinted in 32 ILM 1661 (1993).

${ }^{147}$ The most exhaustive recent overview of the debate over universality and cultural relativism, surveying in one place all of the various substantive, political, and geographic manifestations of the issue, can be found in BREMS, supra note 140 .

${ }^{148}$ Obviously, the European Court of Human Rights and the Inter-American Court of Human Rights are exceptions.

${ }^{149}$ ICCPR, supra note 45, Art. 14(1).

${ }^{150}$ ICESCR, supra note 45 , Art. 2.

${ }^{151}$ See, e.g., Optional Protocol to the International Covenant on Civil and Political Rights, Dec. 19, 1966, Art. 2, 999 UNTS 302; American Convention on Human Rights, Nov. 22, 1969, Art. 46(a), 1144 UNTS 123; European Convention for the Protection of Human Rights and Fundamental Freedoms, opened for signature Nov. 4, 1950 , Art. $35(1), 213$ UNTS 222.
} 
the treaties themselves do not specify that domestic law must follow any particular pattern of incorporation. Rather, the relationship of international treaties to domestic law will be subject to the requirements and possibilities of domestic constitutional and statutory law. While some states will allow for the direct applicability of human rights treaties, others will internalize the international norms through legislation, and still others may maintain an entirely dualist approach that gives international law no domestic effect at all. ${ }^{152}$ In sum, in addition to the relative underdetermination of the norms of human rights, the mechanisms of implementation and enforcement accord very wide latitude to states.

The interesting question here is how these features are understood more generally. Is the normative thinness of the law really due only to its "immaturity"?-which would imply that time and nurture will inevitably lead to further growth, and to the continued transfer of authority over the generation and supervision of norms to the international level. ${ }^{153}$ To what extent is the discretion of states truly a weakness of the human rights system, and by what measure should we answer that question? If it is the case that the international human rights system is inherently structured to support some degree of decentralization of both the determination of the content of human rights norms and their implementation in specific circumstances, how is it related to the idea of state sovereignty, which human rights is supposed to trump? Returning now to the place of sovereignty in the structure of international human rights law, we can see the usefulness of subsidiarity in addressing these questions. Even if the principle of subsidiarity cannot generate mechanical answers, as I emphasized earlier, it can still make sense of the discretion accorded to states to interpret and implement human rights, at the same time that it provides a basis for determining the appropriate limits of that latitude and for justifying intervention and assistance.

\section{Sovereignty vs. Subsidiarity}

One way to understand the latitude of states regarding the interpretation and implementation of human rights is to see it as generated by the difficulty of reconciling state sovereignty with our aspirations to affirm universal values. In this view, the current scope of state discretion and autonomy to interpret and implement international human rights results from the demands of sovereignty that international law not intrude into the internal order of states without being mediated by national law, politics, and institutions. That is, state autonomy and discretion is a manifestation of the continued priority of sovereignty over human rights. ${ }^{154}$

This opposition between sovereignty and human rights presents itself in some way in almost every area of the law and politics of human rights, ${ }^{155}$ including in debates on such issues as the place of the customary international law of human rights in U.S. federal courts, ${ }^{156}$ the

\footnotetext{
${ }^{152}$ See Antonio Cassese, Modern Constitutions and International Law, 192 RECUEIL DES CoURS 331 (1985 III).

${ }^{153}$ In fairness to Philip Alston, from whom I borrow the reference to "immaturity" here (see supra note 118), it should be acknowledged that he was one of the first human rights scholars seriously to question the need for and wisdom of an unchecked expansion of international human rights norms. Philip Alston, Conjuring up New Human Rights: A Proposal for Quality Control, 78 AJIL 607 (1984).

${ }^{154}$ For a strong example of this characterization, see Jack Donnelly, State Sovereignty and International Intervention: The Case of Human Rights, in BEYOND WESTPHALIA? STATE SOVEREIGNTY AND INTERNATIONAL INTERVENTION 115 (Gene M. Lyons \& Michael Mastanduno eds., 1995).

${ }^{155}$ INTERNATIONAL. HuMAN Rights IN CONTEXT 573-74 (Henry Steiner \& Philip Alston eds., 2d ed. 2000); see also Robert Araujo, Sovereignty, Human Rights and Self-Determination: The Meaning of Intermational Law, 24 FORDHAM INT'L.L.J. 1477 (2001) (generally summarizing position of human rights in international law vis-à-vis sovereignty).

${ }^{156}$ Curtis A. Bradley \& Jack L. Goldsmith, Customary International Law as Federal Common Law: A Critique of the Modern Position, 110 HARV. L. REV. 816 (1997) (challenging the position that customary international law is part of federal common law); Harold Hongju Koh, Is International Law Really State Law? 111 HARV. L. REv. 1824 (1998) (critiquing Bradley \& Goldsmith's argument); Gerald L. Neuman, Sense and Nonsense About Customary International Law: $A$ Response to Professors Bradley and Goldsmith, 66 FORDHAM L. REV. 371 (1997). Much of the argument revolves around the history of federal common law and the allegedly "new" character of recent customary international law, and
} 
observance of human rights in China, ${ }^{157}$ and the jurisdiction of the newly created International Criminal Court, ${ }^{158}$ to take just a few recent and contentious examples.

Either implicitly or explicitly, state sovereignty occupies a central place in these discussions-both to those who would regard the degree of autonomy of states characteristic of current human rights law as a fundamental weakness to be overcome, ${ }^{159}$ and to those who see such state autonomy as laudable and necessary for the preservation of the nation's integrity. ${ }^{160}$ What both views have in common is an understanding of international human rights law as structured by a fundamental dichotomy, or rather a set of interrelated dichotomies. On one side are the sovereign nation, local culture, and political legitimacy. Often the national constitution is held up as the synthesis of these values, a symbol invested with the freedom and integrity of a people. On the other side are international, indeed universal, values that are thought to transcend the particularism of the nation and to represent global longings for freedom and justice, for solidarity and a cosmopolitan culture. Both sides can be seen in more negative terms as well, of course: sovereignty then becomes exclusion, intolerance, and viciousness; universalism is viewed as a construct of Western hegemony and imperialism. Whether defending the good of the nation against the threat of imperialist intrusion or affirming the good of universal principles of justice against parochial insularity, these approaches share a central preoccupation with a polarized separation of sovereignty and internationalism. In this model, both the goal and the danger of international human rights law can be expressed as a question of sovereignty and its erosion.

The problem is that the idea of "sovereignty," by itself, tells us absolutely nothing about how to resolve this anxious dialectic between universal and particular. To the extent that the concept of sovereignty is used as an empirical measure of power and autonomy in the international order, it obviously does not justify normative conclusions but merely describes the transient powers of states in international affairs. ${ }^{161}$ Less obvious, but more important, sovereignty as a legal concept is equally empty of fixed, determinate content, as Martti Koskenniemi has definitively shown in his dissection of the doctrine. ${ }^{162}$ Its invocation in international legal argument perpetually oscillates between what Koskenniemi has called "pure fact" and "pure

neither the merits nor the details of those arguments are relevant to the discussion here. It is more interesting for our purposes to observe how much of that debate, on both sides of the issue, is really about the sovereign independence of the United States vis-à-vis the international community and especially international human rights law-particularly a notion of sovereignty couched in arguments about democracy. Peter Spiro has rightly identified this core to the position of Bradley, Goldsmith, and others: "At the center of their thinking stands the edifice of sovereignty. Sovereignty, in this conception, calls for America to resist the incorporation of international norms and drapes the power to do so in the mantle of constitutional legitimacy." For that reason, he dubs the group collectively as "the New Sovereigntists." Peter J. Spiro, The New Sovereigntists. American Exceptionalism and Its False Prophets, FOREIGNAFF., Nov./Dec. 2000, at 1. In response, Bradley and Goldsmith just as plausibly label Spiro's position one of "unalloyed internationalism" that does not take sufficiently serious account of the importance of national consent to international obligations. Curtis A. Bradley \& Jack L. Goldsmith, Letter to the Editor, FoREIGNAFF., Mar./Apr. 2001 , at 188, 189. It is at least suggestive that Bradley and Goldsmith's quarrel with Spiro's "New Sovereigntist" tag is not with the "sovereigntist" part of the phrase but with the alleged "newness" of it.

${ }^{157}$ See, e.g., Juangyu Wang, China and the Universal Human Rights Standards, 29 SYRACUSE J. INT'L L. \& COM. 135, $139,146-49$ (2001) (emphasizing China's historical assertion of state sovereignty against human rights).

${ }^{158}$ See generally THE UNITED STATES AND THE INTERNATIONAL CRIMINAL COURT: NATIONAL SECURITY AND INTERNATIONAL LAW (SarahB. Sewall \& Carl Kaysen eds., 2000).

${ }^{159}$ E.g., Louis Henkin, That "S" Word: Sovereignty, Globalization and Human Rights, 68 FORDHAM L. REV. 1 (1999); Louis Henkin, Human Rights and State "Sovereignty, " 25 GA. J. INT'L \& COMP. L. 31 (1995).

${ }^{160}$ E.g., Araujo, supra note 155 , at 1485 (noting that "[a] sovereign nation is a community of people who exercise shared values concerning human dignities that shape and direct the particulars of their communitarian selfdetermination").

${ }^{161}$ We can only wonder what will become of sovereignty in this sense as a result of the current era of globalization. See, e.g., John O. McGinnis, The Decline of the Western Nation States and the Rise of the Regime of International Federalism, 18 CARDOZO L. REv. 903, 918 (1996); Alfred van Staden \& Hans Vollard, The Erosion of State Sovereignty: Towards a Post-Territorial World? in STATE, SOVEREIGNTY, AND INTERNATIONAL GOVERNANCE 165 (Gerard Kreijen ed., 2002).

${ }^{162}$ MARTTI KOSKENNIEMI, From APOLOGYTO UTOPIA: THE STRUCTURE OF INTERNATIONAL LEGALARGUMENT, ch. $4(1989)$. 
law" approaches- that is, approaches that begin either from the empirical fact of state liberty external to the law, or from a Kelsenian conception of legal order that preexists and thus controls the sovereignty of the state. ${ }^{163}$ As Koskenniemi observes:

It is impossible to define "sovereignty" in such a manner as to contain our present perception of the State's full subjective freedom and that of its objective submission to restraints to such freedom. If we start by associating sovereignty with an initial, aprioristic freedom of the State, we shall either have to conclude that no State is free or that the international order is not really binding. If sovereignty is associated with the momentary set of rights, liberties and competences given by the normative order to the State, then we shall have to reject the idea that the State would be free to do anything which it is not specifically empowered to do. ${ }^{164}$

Because the positions are mutually exclusive, yet each untenable on its own, each is explained and justified in terms of the other, and ultimately the choice between them in a specific context turns on values or referents external to legal argumentation itself. ${ }^{165}$

Koskenniemi does not conclude from this reasoning that sovereign statehood should be abandoned but, rather, that despite the self-contradictions of state sovereignty, "as long as there is no wide agreement on what constitutes the good life, the formality of statehood remains the best guarantee we have against the conquest of modernism's liberal aspect by modernism's authoritarian impulse." ${ }^{166}$ In other words, he regards sovereign statehood as a "second best"-worthy of protection in international law but not unreservedly so-because he takes for granted the modernist project's denial of natural justice. ${ }^{167}$ Whether or not Koskenniemi is correct in presuming so categorically our incapacity to reach general agreement about "the authentic purpose of social life," he is right that making sense of sovereignty does seem to require some injection into it of substantive values that come from outside international law. For that reason, he correctly observes that recent efforts to rethink the nature of international law either have abandoned normativity altogether ${ }^{168}$ or else have sought to refashion the idea of sovereign statehood through "a doctrinal and practical turn towards equally indeterminate, less pretentious and more responsive notions of reasonableness, balance, and justice." 169

The latter efforts are apparent, among other ways, in various attempts to remake sovereignty so that the substantive manner in which it is legitimated and exercised is taken into account. For instance, moves toward international legal recognition of "popular sovereignty"170 or "responsible sovereignty" ${ }^{171}$ can be understood as attempts to give form to the empty garment of "sovereignty" by reintroducing into it substantive values principally grounded in political liberalism. Liberal internationalism, especially that most explicitly associated with international relations theory, provides one way of thinking about the structural characteristics and problems of human rights that does not fall into the limited categories of a classic sovereignty analysis. As Anne-Marie Slaughter notes, "from a Liberal perspective, $a$-if not theprimary function of public international law is . . to influence and improve the functioning of domestic institutions," and this concern for internal legal order also means that "[f]rom the

${ }^{163} \mathrm{Id}$.

${ }^{164} I d$. at 211 (footnote omitted).

${ }^{165} \mathrm{Id}$. at 234-35, 262-63.

${ }^{166}$ Martti Koskenniemi, The Future of Statehood, 32 HARV. INT'L L.J. 397, 397 (1991).

${ }^{167}$ Id. at 407; KosKENNIEMI, supra note 162, at 933.

${ }^{168}$ E.g., DAVId KENNEDY, INTERNATIONAL LEGal. STRUCTURES (1986).

${ }^{169}$ Koskenniemi, supra note 166 , at $407,409$.

${ }^{170}$ E.g., W. Michael Reisman, Sovereignty and Human Rights in Contemporary International Law, 84 AJIL 866 (1990).

${ }^{171}$ Richard Falk, Sovereignty and Human Dignity: The Search for Reconciliation, in AFRICAN RECKONING: A QUEST FOR GOOD GOVERNANCE 12 (Francis M. Deng \& Terrence Lyons eds., 1998). 
perspective of Liberal theory, human rights law is the core of international law." 172 Because liberal international relations theory attends to the internal character of states, it has the capacity to see international human rights norms and institutions as directed toward the sovereign integrity of (liberal) states at the same time that it can explain intervention in states where liberal values have broken down or been threatened. ${ }^{173}$ Thus, liberal internationalism does not reject sovereignty altogether but seeks to reorder the hierarchy of values in the international order so that sovereignty becomes a subordinate function of internal, liberal political values, especially human rights. ${ }^{174}$

Although the substantive values on which subsidiarity is based-its implicit presuppositions of personhood and society-differ somewhat from those of liberalism (or at least most forms of liberalism), ${ }^{175}$ it does share some features with liberal internationalism. Both seek a politics and law that integrates internal and international orders, and both emphasize a notion of individual flourishing that can be expressed at least in part through the language of human rights. Like liberal international theory, subsidiarity also affords an alternative way of thinking about the relationship between states (and substate associations) and international order in matters of human rights beyond the rigid and ultimately empty dichotomies of "sovereignty."

In the second part of this article, we saw that the European Union employs the concept of subsidiarity as an alternative to the impasse of pitting the sovereign member state against the Union's supranational authority. It is meant to help delineate competences according to criteria that empower the larger body to accomplish its aims effectively, without unnecessarily removing power and discretion from the ambit of local control. A subsidiarity-oriented understanding of human rights and international law does not care to ask whether "state sovereignty" must either resist or give way to international harmonization and intervention but, instead, whether the good that human rights aim at realizing can be accomplished at the local level, and if not, what assistance is necessary from a more comprehensive association to enable the smaller unit to realize its role.

Thus, rather than understanding larger and more universal forms of human association to be in competition with the smaller and more local, as a sovereignty-oriented paradigm does, subsidiarity posits a model of assistance and cooperation. The goal is an integration that values the autonomy and self-sufficiency of the more specific group and places a responsibility on the higher one to intervene without interference, to assist but not usurp.

"Nothing is absolutely sovereign in the world of subsidiarity," Endo has remarked. ${ }^{176}$ In at least four important ways a subsidiarity-oriented perspective will differ from a sovereigntybased one. First, at the descriptive level subsidiarity makes better sense of the existing structure of states in international human rights law described earlier. From the perspective of sovereignty, the law's reliance on national legal systems for normative content and effective supervision and implementation of human rights is either a profound weakness to be overcome by the progress of internationalism or a necessary bulwark to be maintained against the forces inimical to local integrity and self-governance. Those positions make it difficult to arrive at any nuanced or gradated judgment about the balance between local autonomy and international

\footnotetext{
${ }^{172}$ Anne-Marie Slaughter, A Liberal Theory of International Law, 94 ASIL PROC. 240, 246 (2000). For a more specific application of liberal internationalism to the question of sovereignty, intervention, and human rights, see Gregory H. Fox, New Approaches to International Human Rights: The Sovereign State Revisited, in STATE SOVEREIGNTY: CHANGE AND PERSISTENCE IN INTERNATIONAL RELATIONS 105 (Sohail H. Hashmi ed., 1997).

${ }^{179}$ See, e.g., Fox, supra note 172.

${ }^{174}$ See Slaughter, supra note 172 , at 246.

${ }^{175}$ This is obviously not the place for a comprehensive treatment of the differences between liberal theory and subsidiarity. Here I would simply note that such an analysis would have to focus at least in part on the differences between the comprehensively personalist orientation of subsidiarity and the more limited concept of liberty implicit in liberal theory, as well as the balance between intervention and noninterference that might flow from their distinctive understandings of freedom.

${ }^{176}$ Endo, supra note 86, at 34.
} 
community. ${ }^{177}$ From the perspective of subsidiarity, however, it is possible and even necessary to say coherently that the system should both rely primarily on the most local body capable of giving meaning and effect to human rights and accord authority and responsibility to larger, more comprehensive bodies to intervene so as to assist in the realization of human rights. At a more formal doctrinal level, this means that a subsidiarity analysis can more fully take into account the purpose and value of such substantive rules as the margin of appreciation and such procedural devices as the exhaustion of local remedies, but also the dangers they pose and limitations to which they should be subject. Both subsidiarity and sovereignty recognize the capacity and responsibility of local bodies with respect to human rights, and treat international intervention as properly supplemental or subsidiary. Thus, to use an example that I relied upon earlier, subsidiarity can explain the need for a system of reservations to human rights treaties and yet provide a norm for limiting and controlling them, while the sovereignty-vs.-human rights paradigm seems either to freely permit reservations or to oppose them altogether, or else to persist in the coexistence of mutually contradictory goals in the governing legal doctrine.

Second, subsidiarity necessarily goes beyond the rigid dualism of states on one side and international community on the other, and includes in its ambit a variety of sub-and supranational levels of association and authority in human rights. The more traditional notions of sovereignty do not adequately take into account international law's "multi-layered reality consisting of a variety of authoritative structures." 178 This is true both at the substate level, where intermediary bodies of civil society play a critical role in the development of and respect for human rights, ${ }^{179}$ and at the suprastate level, where the relationship between global and regional human rights systems helps realize universal norms through the accommodation of diversity. ${ }^{180}$ Subsidiarity is a way of recognizing the truth of Nicolas Valticos's conclusion that "through the plurality of international juridical orders, the profound unity of international law, though still imperfect, is revealed."181

This point brings us to the third difference between subsidiarity and sovereignty-based understandings: the former constitutes a better foundation for the value of and respect for diversity and pluralism within the global community. From a sovereignty-oriented perspective, diversity is a consequence of the autonomous equality of states, and stands in uneasy tension with the universalizing aspirations of international human rights. However, as we saw in the first section of this article, subsidiarity envisions a diversity based not just in tolerance of difference but in a genuine pluralism in the understanding and pursuit of a unified good. Thus, the idea of subsidiarity does challenge sovereignty by violating the first premise of the modern project of international law, as Koskenniemi describes it, because it proposes a substantive

\footnotetext{
${ }^{177}$ E.g., Ivan Simonovic, State Sovereignty and Globalization: Are Some States More Equal? 28 GA.J. INT'L \& COMP. L. 381 (2000). Simonovic attempts to address the dilemmas of globalization by applying a "sovereignty vs. interventionism" dichotomy that reduces every state's choice merely to "whether to maintain the old version of sovereignty, trying to protect all their traditional rights, or to accept international authority to interfere into some areas that were previously in their exclusive competence." Id. at 398. Similarly, another scholar is reduced to summarizing the relationship between sovereignty and international concern in the inter-American human rights system as "you win some, you lose some." Frits Kalshoven, State Sovereignty versus International Concern in Some Recent Cases of the InterAmerican Court of Human Rights, in STATE, SOVEREIGNTY, AND INTERNATIONAL GOVERNANCE, supra note 161, at 259, 259.

${ }^{178}$ Christoph Schreuer, The Waning of the Sovereign State: Totwards a New Paradigm for International Law? 4 EUR. J. INT'L L. 447, 453 (1993).

179 See Andrea Bianchi, Globalization of Human Rights: The Role of Non-State Actors, in GLOBAL LAW WITHOUT A STATE 179 (Gunther Teubner ed., 1997); Kathryn Sikkink, Human Rights, Principled Issue-Networks, and Sovereignty in Latin A merica, 47 INT'L ORG. 411 (1993).

${ }^{180}$ Cf. George William Mugwanya, Realizing Universal Human Rights Noms Through Regional Human Rights Mechanisms: Reinvigorating the African System, 10 IND. INT'L \& CoMP. L. REv. 35 (1999); Dinah Shelton, The Promise of Regional Human Rights Systems, in The Future OF INTERNATIONAL HuMAN Rights 351 (Burns H. Weston \& Stephen P. Marks eds., 1999).

${ }^{181}$ Nicolas Valticos, Pluralité des ordres juridiques intermationaux et unité du droit international, in THEORYOF INTERNATIONAL LAW AT THE THRESHOLD OF THE 21ST CENTURY 301, 322 (Jerzy Makarczyk ed., 1996) (my trans.).
} 
vision of the meaning of the social life of humanity, a common good that is ultimately directed toward the dignity of socially oriented human persons. But the paradox of subsidiarity is its simultaneous emphasis on a real differentiation within this good, resulting from a comprehensive understanding of human freedom. As a result, it can embrace both the universal impetus of the idea of human rights and the relative autonomy of states and other local communities. In this way subsidiarity seeks to overcome the bind of modernism that Koskenniemi laid out-the problem of basing international order on some substantive conception of the good without succumbing to the temptation of authoritarianism.

Finally, a subsidiarity perspective, in contrast to a sovereignty view, helps integrate more fully the basic underlying values of human rights, the dignity and freedom of the human person in society, with international law generally. It is a commonplace that the premises of international human rights relate very uncomfortably to the sovereign-state paradigm of international law. ${ }^{182}$ To some, it may be a question of the need to adapt and develop the traditional understanding of international law, ${ }^{183}$ while others see the problem as much more of a structural contradiction between the parent discipline of international law and its awkward human rights stepchild. ${ }^{184}$ Moving from sovereignty to subsidiarity provides a possible foundation for reconciling the concern of international law for the order of states with the concern of human rights law for the welfare of individuals, because both are understood to be incorporated into a broader common good. The international law between states does not become obsolete or unnecessary, but is placed in integral relationship to internal society. ${ }^{185}$

In sum, subsidiarity departs from sovereignty-based perspectives on human rights in international law in ways that give it both descriptive and prescriptive usefulness. It explains certain aspects of the existing structure of international human rights law more fully and accurately than understandings that crudely pit sovereignty against human rights, and it also provides a more substantive criterion of judgment to evaluate and critique them. It aligns human rights and the international order of states along a more coherent axis that turns on a common good of human dignity and freedom, and around which circle both the local and the global, the particular and the universal, the unified and the diverse. Its paradoxical quality helps keep alive the unceasing tension between the competing ideals of belonging to a particular and affirming a universal unity and helps avoid the collapse of international law into either the romanticism of the nation-state or the ideological abstraction of "pure" internationalism.

\section{SUbSIDIARITY AND PLURALISM IN HUMAN RightS}

If subsidiarity is to help realize even a small portion of the ideals I have ultimately claimed for it, the heavy lifting of the concept is done by the fact that, coupled with human rights, it purports to affirm a universal common good while still requiring ample room for pluralism

${ }^{182}$ ANTONIO CasseSe, INTERNATIONAL LAW IN A Divided WORL. 148 (1986); Alston, supra note 118, at xii-xiv.

${ }^{183}$ Alston, supra note 118 , at xii-xiv.

${ }^{184}$ Koskenniemi, supra note 166 , at $397-400$.

${ }^{185}$ Subsidiarity in this way proposes a reconceptualization of the international society not unlike that sought by Philip Allott in his monumental EUNOMIA: NEW ORDER FOR A NEW WORLD (1990). Allott would have us pursue the humanization of the state system by reconceiving international law as international society. Id. at 254, para. 14.1. In this transformation, he sees human rights as affirming both the unity of human nature and the plurality of human values by providing "a model or pattern or formula of the reconciling of the good of each member of society and the good of society within a good which transcends society." Id. at 287, para. 15.64; see also id. at 286, para. 15.63. At the same time, the humanization of international society will result, for Allott, in a change both in vocabulary and in self-conception that, among other things, would lead to the disappearance of the words "sovereign" and "sovereignty" from the vocabulary of international law and society. Id. at 310-11, para. 16.34. Although Allott does not offer the word "subsidiarity" as a replacement, it is a concept that would ideally fit his aspirations. He diagrams his understanding of "the good order of a self-ordering society" with a circle that connects "individual human being," "subordinate societies," "international society," and "Universe of all-that-is" around the ideals of "justice/humanity/love." Id. at 404, para. 18.77. It could well be described as an illustration of the ideal of subsidiarity, too. 
in the concrete determination and application of that good. This quality is principally what allows it to sidestep the dilemma and incoherence of sovereignty. The first to be alarmed by that conclusion might well be those for whom state sovereignty still is and ought to remain a shield against too-intrusive international human rights norms. This reaction would be understandable, for there is no mistaking that subsidiarity preserves and even enhances the assumption that human rights is a matter of international concern and action. As we saw in the preceding discussion, the idea of subsidiarity leaves no room for sovereignty as such. For the reasons set out there, however, I have already argued for the superiority of the principle of subsidiarity. In this part, I want to address the opposite (and in my opinion much more serious) concern. From the perspective of prevalent human rights thinking, a subsidiarity-oriented approach to international human rights is the source of potential problems more because of its affirmation of diversity than because of its universal values. The pluralism in human rights that subsidiarity justifies may be thought to be both superfluous and dangerous, threatening to contradict the core ideas of hurnan rights and to fragment their already thin coherence and viability in international law.

One might ask whether the value subsidiarity accords to pluralism is necessary at all in light of existing international law. As shown by the discussion in part III above, a variety of doctrines and practices exist that structurally permit some degree of pluralism in international human rights. If my assessment is correct that these demonstrate in part that subsidiarity is already implicitly present in the structure of international human rights law, then one can reasonably wonder why those doctrines do not suffice by themselves, and whether the label of "subsidiarity" is in reality little more than a nominal innovation. Why introduce a new term for them? The doctrine of the margin of appreciation, in particular, arguably provides a possible foundation for valuing diversity in human rights even outside the European system, ${ }^{186}$ and in some ways it so closely resembles the idea of subsidiarity that some commentators have occasionally used the two terms as synonyms. ${ }^{187}$ ?

A closer comparison, however, reveals several important differences between them, and advantages to understanding human rights in terms of subsidiarity. The first has to do with the comprehensive character of subsidiarity when compared with other concepts. The margin of appreciation, for instance, is basically a doctrine of judicial decision making in specific cases. ${ }^{188}$ It does not pretend to be a broad principle describing the politico-legal structure of human rights as a whole, but is instead aimed at reaching the best outcome on a case-bycase basis. I have argued here that subsidiarity pervades international human rights law, starting from its basic theoretical orientation and extending to its relationship with other fundamental principles of classic international law such as state sovereignty. Unlike the margin of appreciation, therefore, subsidiarity is relevant to all aspects of international human rights law and politics, not just formal adjudication: legislation, enforcement, intervention, assistance, and cooperation, to name some of them. To put it another way, the various techniques for embedding diversity in international human rights might be thought of as limited and partial manifestations, relevant to specific contexts, of the principle of subsidiarity as a whole. Like the leaf of a tree or wheel of a car, the function of the part makes complete sense only in relation to the whole.

\footnotetext{
${ }^{186}$ See, e.g., Douglas Lee Donoho, Autonomy, Self-Governance and the Margin of Appreciation: Developing a Jurispme . dence of Diversity Within Universal Human Rights, 15 EMORY INT'L L. REV, 391 (2001).

${ }^{187}$ See, e.g., Mahoney, supra note 7, at 369; Herbert Petzold, The Convention and the Principle of Subsidiarity, in THE EUROPEAN SYSTEM FOR THE PROTECTION OF HUMAN RIGHTS, supra note 141, at 41 .

${ }^{188}$ BREMS, supra note 140, at 422 (concluding after an exhaustive discussion of the margin of appreciation that " $[\mathrm{m}]$ argin of appreciation techniques are not so much a solution to the universality-diversity problem as a tool for reaching solutions in specific cases," and noting problems that would accordingly arise in using the doctrine on a more universal level).
} 
Subsidiarity can reasonably be understood as the "whole" in this sense basically because, unlike the recognized doctrines of diversity, it has a firm theoretical foundation that embraces the premises and values of human rights themselves-as we saw in part I above-rather than some competing external value, like state sovereignty. The same cannot be said of the margin of appreciation. Because of its purpose as a justification for adjudication in particular cases, the margin of appreciation tends to suffer from a very thin analytical basis, as many of its critics (and even some of its proponents) have pointed out. ${ }^{189}$ When it is given a more articulated grounding, it is most often tied to a pragmatic search for some unspecified degree of "consensus" among the states party to the treaty. ${ }^{190}$ As I have argued elsewhere, such comparative exercises have important uses in human rights jurisprudence, but purporting to serve as a firm basis for determining the appropriate scope of state discretion is not one of them. ${ }^{191}$ One of the more straightforward and plausible explanations for the margin of appreciation is that it marks the boundary between human rights and state sovereignty: "Where the one ends, the other begins," J. G. Merrills noted. ${ }^{192}$ In other words, the margin of appreciation, by itself, returns us squarely to the problem discussed and rejected in part III: understanding the structure of pluralism in international human rights as arising out of the basic opposition of human rights and sovereignty, rather than (as subsidiarity suggests) as a necessary and integral part of the idea of human rights itself.

None of that is to say that the doctrines of diversity, and especially the margin of appreciation, have nothing to offer us in this discussion. On the contrary, the study and practical experience of the margin of appreciation and other partial expressions of subsidiarity have a great deal to contribute in helping us assess the more serious and complex objections to pluralism in human rights: that affirmations of pluralism in any form pose a grave danger to the human rights project. This challenge contains within it several related concerns. To get at them more carefully, just as we did with the principle of subsidiarity itself, we can consider the issue by extending arguments raised in the context of the European Union into international human rights more generally.

One of the most direct cases made against pluralism in the interpretation and application of the fundamental rights law of the European Union is that of Leonard Besselink. ${ }^{193}$ Besselink raises three basic kinds of objections. The first is a philosophical argument about the nature of "fundamental" rights. Besselink argues that a pluralistic approach to the protection of human rights logically must undermine, or even destroy, whatever is "fundamental" and "universal" about those rights. This approach, he argues, "is tantamount to positing that fundamental rights are not really fundamental rights; taken to its logical conclusion, the assertion means that rights are not rights at all."194 The second objection is more political, and relates superficially to the constitutional supremacy of EU law but even more broadly to the effectiveness of supranational norms and institutions. Besselink notes that a divergence in levels

${ }^{189}$ See, e.g., GREER, supra note 141, at 32 (noting margin of appreciation's lack of even "minimum theoretical specificity and coherence" and its "pseudo-technical" character); Lord Lester of Herne Hill, Universality Versus Subsidiarity: A Reply, 1998 EUR. HUM. RTS. L.R. 73, 75; Olivier de Schutter, L'Interprétation de la Convention européenne des Droits de l'Homme: un essai en démolition, 70 REVUE DE DROIT INTERNATIONAL, DE SCIENCES DIPLOMATIQUES, POLITIQUES, ET SOCIALES 83 (1992).

${ }^{190}$ See BREMS, supra note 140, at 411-21; KASTANAS, supra note 141, at 186-224, 306-22; YouROW, supra note 141, at 193-96.

191 Carozza, supra note 103.

${ }^{192}$ J. G. MERrilis, THE DEVELOPMENT OF INTERNATIONAL LAW BY THE EUROPEAN COURT OF HuMAN RigHTS 157 (1988); see also BREMS, supra note 140, at 360 ("The margin of appreciation doctrine demarcates the room left for the exercise of national sovereignty."); Michael R. Hutchinson, The Margin of Appreciation Doctrine in the European Court of Human Rights, 48 INT'L\& COMP. L.Q. 638, 647 (1999) (observing that the "problem that prompted the idea was the relationship between a sovereign State party and the supervising organs of the Convention").

${ }^{193}$ Besselink, supra note 7.

${ }^{194} I d$. at 639; see also id. at 668-70. 
of judicial protection of rights within the European Union undermines the primacy of Community law to the point that "the doctrine of legal and political pluralism would mean a definitive end to the doctrine of supranationalism, based as the latter is on a subaltern relationship." ${ }^{195}$ Third, he raises the legal value of uniformity as an obstacle; pluralism would undermine the "uniform and full effect" of the law. ${ }^{196}$ Again, this problem can be broadened to include legal values related to uniformity, such as certainty and predictability; by creating a situation where the same norm of human rights could have a different effect or application in different places, pluralism could be thought to contradict some of the basic principles of the rule of law.

Each of these three arguments, as I will address them in turn in this part, has an equivalent in the broader sphere of international human rights law. In fact, each of them is likely to be even stronger at the global level than in the European Union because the latter's constitutional structure and political process are tighter and more comprehensive, and therefore more capable of controlling and balancing the conflicting values and consequences of subsidiarity. Within the looser fabric of international law, pluralism within human rights may be that much more likely to lead to even greater philosophical incoherence, political ineffectiveness, and legal weakness.

\section{The Philosophical Objection: "Universal," "Fundamental," "Human" Rights}

At first glance, the most comprehensive objection to subsidiarity may be the most intuitively appealing. If the principle creates pluralism in the interpretation and application of rights, then it must certainly undermine, or even destroy, whatever is "fundamental" and "universal" about human rights. How could they even be "human" unless they belong to all humans irrespective of the accidents of time and place in which they find themselves?

The problem is that this view clearly misunderstands the way human rights can be said to be either "universal" or "fundamental." The confusion arises from the conflation of the broad principles of human rights and their instantiation in a specific set of contingent circumstances. Any statement of a human right when abstractly proposed can be said to be fundamental and universal to the extent that it expresses part of the requirements of justice and human dignity for every human being, that is, to the extent that it expresses in the language of rights some aspect of the common good. In that case, it is "fundamental" in the sense that it is necessary to the realization of human dignity and the common good, and it is "universal" because it is necessary to the realization of human dignity and the common good in every society. ${ }^{197}$ But it cannot be supposed that the accidents of culture, language, history, institutional and political circumstance, economic organization, and the myriad other differences that separate any one society from another across time and space are irrelevant to putting even fundamental and universal principles into practice. ${ }^{198}$ Even if an abstract notion like a "human right" can reasonably be said to be necessary to the realization of the common good in all societies, the specification of that concept of "right" will depend on varying conceptions of who the holders of the right and the correlative duty are, or the conditions under which the right claim is lost or waived, and so on. ${ }^{199}$ Thus, even when a right can properly be termed

${ }^{195}$ Id. at 668 .

${ }^{196}$ Id. at 678; see also id. at 671.

${ }^{197}$ Cf. PERRY, supra note 50, at 65 (defining "universalism" in context of the relativist challenge to human rights as affirming that "some things good for some human beings are good for every human being and some things bad for some human beings are bad for every human being").

${ }^{198}$ See Max L. Stackhouse, Reflections on "Universal Absolutes, "14 J.L. \& RELIGION 97 (1999) (arguing that although human rights are "absolute" moral first principles, there will always be variations about how to specify and clarify the absolutes in concrete circumstances).

${ }^{199}$ See FiNNIS, supra note 27, at 218-21. 
fundamental and universal, it may still, and probably will, differ in its instantiation in positive law in a given context. ${ }^{200}$ The move from primary principles expressing basic human goods to positive law is not a process of deduction, because the first principle can inevitably be given effect in various reasonable ways. That move is rather an activity of practical reason known in the natural law tradition as determinatio, an exercise of creative freedom to legislate in different ways that may be equally consistent with the basic requirements of the common good. ${ }^{201}$ In short, the engagement of human freedom means that universality of principle does not and ordinarily cannot require uniformity of application.

More specifically, one way that the positive expression of an abstract universal right will depend on context is in its relationship to the positive realization of other universal rights. As specific aspects of a single common good, fundamental rights can rarely, if ever, be understood to exist except in relation to other rights. ${ }^{202}$ Thus, while it is possible to say in general that the common good requires recognition of a fundamental right to freedom of the press, in a concrete, functioning system of law the precise scope and contours of that right will often be defined by balancing it against other aspects of the common good, for example, freedom of the press versus protection of an individual's private life, dignity, and reputation. Examples of that balancing are as endless as the boundaries of human activity, including freedom of speech versus peace, security, and protection from the propaganda of hate and degradation; freedom to associate or to practice and profess a religion versus protection from unequal treatment; and the right to health care versus the allocation of societal resources to other pressing social needs. In each case, the balancing of the different aspects of the common good can be done in different ways, and every interpretation of the scope of a right involves some assessment of the reasonableness of balancing different, specific aspects of the common good.

As long as in at least some instances local bodies would be better suited to making that assessment and would make different, but reasonable, distinctions in the determinatio of general principles of human rights, subsidiarity and its potential for pluralism would not in principle contradict the universal or fundamental character of the rights. In such instances the experience of normative pluralism gained through the use of the margin of appreciation doctrine can help us. The European Court of Human Rights has identified a variety of circumstances

\footnotetext{
${ }^{200}$ Erhard Denninger goes so far as to argue that the "universal" character of human rights and their dependence on a specific political-legal order are "inseparably connected" because although the point of reference of "human rights" is every human being in general, as concrete subjects of rights those human beings can be understood only within particular legal orders and value systems. ERHARD DENNINGER, DIRITTI DELL'UOMOE LEGGE FONDAMENTALE 58 (Carlo Amirante ed. \& trans., 1998).

${ }^{201}$ See, e.g., George, supra note 114, at 62-64. George explains the meaning of determinatio further:

Unfortunately, no single word in English adequately captures the meaning of determinatio. "Determination" has some of the flavor of it; but so do "implementation," "specification," and "concretization." The key thing to understand is that in making determinationes, the legislator enjoys a creative freedom that Aquinas analogizes to the freedom exercised by an architect. An architect must design a building that is sound and sensible for the purposes to which it will be put. Ordinarily, however, he cannot identify a form of the building that would be uniquely suitable. A range of possible designs will likely satisfy the relevant criteria. Obviously, a design with "doors" no more than three feet high is unlikely to meet an important requirement for a functional building. No principle of architecture, however, sets the proper height of a door at six feet two inches as opposed to six feet eight inches. In designing a particular building, the architect will strive to make the height of the doors make sense in light of a variety of factors, some of which are themselves the fruit of determinationes (the height of the ceilings, for example); but even here he will typically face a variety of acceptable but incompatible design options.
}

Id. at 62-63; see also FINNIS, supra note 27, at 281-90.

${ }^{202}$ Cf. FinNIS, supra note 27, at 214-18. Although taken here most directly from Finnis, this insight is by no means exclusive to natural law reasoning. For example, Joseph Raz arrives at a similar conclusion from a different philosophical perspective: "Rights and their boundaries demarcate the degree to which individual and common interests with (the protection of) which the rights under discussion are concerned are to be protected when they clash with other individual and common interests." Joseph Raz, Rights and Politics, in LAW, VALUES AND SOCIAL.PRACTICES 75, 86 (John Tasioulas ed., 1997). 
in which local specification of human rights can be considered reasonable: ${ }^{203}$ local decisionmaking institutions may often benefit from a better understanding than more distant authorities of the constitutional traditions of their nation and the particular inflections and accents of human rights discourse in their social and political context; they may frequently have access to better or more complete information for making their decisions; they may be more sensitive to the popular legitimacy of certain decisions at the margins of rights jurisprudence; and they may enjoy more institutional legitimacy than supranational bodies among the people affected by the decisions.

Of course, there are also conditions that could make local authorities less suited in some instances to reaching a reasonable result. ${ }^{204} \mathrm{But}$ my point is that in principle the idea of fundamental and universal human rights is compatible with local decisions over their scope and application. The margin of appreciation does not destroy the "universal" or "fundamental" character of the rights. It merely recognizes that the specification of general principles of human dignity in concrete political and social situations will very often require a complex and uncertain balance of values and the exercise of difficult choices of political morality. ${ }^{205}$ Thus, while any one solution might be compatible with the broadly understood requirements of human dignity and the common good, no two are likely to be identical. By recognizing this feature, the margin of appreciation doctrine creates what Mireille Delmas-Marty has called a "heterogeneous space" where "the principle of identity ... is replaced by the principle of proximity." ${ }^{206}$ Indeed, a persistent theme of Delmas-Marty's work in legal theory has been to show that this normative pluralism is entirely consistent with the overall rationality and coherence of the European human rights system. ${ }^{207}$

The idea of "universal" or "fundamental" rights, in sum, does not contradict in principle or practice the reasonableness and recognition of pluralism in the specification of a conception of the human good to which human rights refer. ${ }^{208}$ Therefore, it does not defeat the application of subsidiarity to human rights. On the contrary, the freedom and human dignity sought to be achieved through the adequate protection of human rights will be most fully realized where the decision over the reasonable balancing of aspects of the common good is taken at the closest level to the affected person as is effectively possible. As noted in the first part of this article, this ordered liberty to realize the unity of a common good in diverse ways underlies both human rights and subsidiarity.

\section{The Political Objection: The Effectiveness of Human Rights Norms}

Opposing pluralism in fundamental rights because it would undermine the primacy of supranational law in the European Union amounts in the end to an argument regarding the effective force of supranational norms generally. If states subject to the same normative constraints at the international level can nonetheless interpret and apply those norms in a divergent fashion based on their local understandings, it is not hard to see why Besselink sees pluralism as threatening a "definitive end to ... supranationalism." ${ }^{209}$ In the European Union, of course, this argument has a particular import because of the constitutional context. Just

\footnotetext{
${ }^{203}$ Discussion of most of the following criteria, and citations to relevant ECHR cases, can be found in BREMS, supra note 140 , at $357-422$.

${ }^{204}$ See part V infra.

${ }^{205}$ Cf. WEILER, supra note 88, at 103-07 (discussing this idea specifically in the context of the European Union's fundamental rights jurisprudence).

${ }^{206}$ Mireille Delmas-Marty, The Richness of Underlying Legal Reasoning, in THE EUROPEAN CONVENTION FOR THE PROTECTION OF HUMAN RIGHTS: INTERNATIONAL PROTECTION VERSUS NATIONAL RESTRICTIONS 319, 330, 332-33 (Mireille Delmas-Marty ed., 1992).

${ }^{207}$ See especially MIREILLE DELMAS-MARTY, LE FLOU DU DROIT (1986).

${ }^{208}$ See PERRY, supra note 50, at 64-71.

${ }^{209}$ See Besselink, supra note 7, at 668 .
} 
as the doctrine of the supremacy of Community law (within its field of application) forms the cornerstone of the constitutionalization of Europe, ${ }^{210}$ so would the lack of any effective supranational law essentially return the Union to a mere collection of states bound together only by the classic model of international treaties. But even within a traditional international law framework, such as that of international human rights treaties, the effectiveness of supranational norms poses a significant challenge. It is hard enough to make international human rights law respected in practice-it is relatively easy for governments to violate human rights, often with a high degree of impunity, and rather difficult to give international institutions real authority. If subsidiarity and legal pluralism are presumed to confer even greater discretion on those national institutions and at the same time to reduce the force of international supervision and enforcement, the political objection is a reasonable and serious one applicable not only to the European Union but to any supranational context.

Subsidiarity may influence the effectiveness of human rights at two levels: in the work of international institutions, and also in the role of domestic ones. In both cases, subsidiarity has the potential actually to strengthen human rights.

Taking the supranational level first, it is again instructive to consider the jurisprudence of the European Court of Human Rights, widely and rightly regarded as the most effective international human rights institution. ${ }^{211}$ One of the interesting questions raised by the history of the ECHR is how its decisions have come to be so fully respected and regarded as authoritative sources of law in the domestic constitutional orders of all of the states party to the European Convention on Human Rights, to the point where the domestic acceptance of the legitimacy of the Court's decisions has succeeded in transforming this international treaty regime into a genuine system of positive law. ${ }^{212}$ Laurence Helfer and Anne-Marie Slaughter have proposed that that transformation has a great deal to do with some of the qualities of supranational adjudication that have characterized the ECHR. According to them, the commitment of the Court to incremental change and its engagement in dialogue with other judicial bodies have figured among the principal factors leading to its effectiveness. ${ }^{213}$ Both of these practices are consistent with, and indeed encouraged by, the principle of subsidiarity.

With regard to incrementalism, Helfer and Slaughter note that the margin of appreciation doctrine is evidence of the ECHR's sensitivity to the tension between local decision making and the progressive development of supranational norms. Recognition of a margin of appreciation has in fact allowed the ECHR to strengthen its legitimacy by incorporating into its techniques of adjudication a healthy degree of deference to national institutions on many issues, especially with respect to the recognition of new applications of the rights recognized in the Convention. The Court thus remains connected to, and not too distant from, those interpretations and applications of the Convention that are accepted within the national settings. Subsidiarity would also encourage a similar connection between a supranational body and local law, politics, and culture that would, when used judiciously, enhance rather than undermine the legitimacy and effectiveness of the higher institution.

The other characteristic of effective supranational adjudication mentioned above was the ECHR's engagement in cross-judicial communication. This commitment to "solidarity" over "insularity," in Helfer and Slaughter's view, strengthens the Court's adjudication by implicitly acknowledging the commonality of the legal problems at issue and their (partial) independence from particular jurisdictional limitations or culturally limited contexts. ${ }^{214}$ In a related

\footnotetext{
${ }^{210}$ See WEILER, supra note 88.

${ }^{211}$ See, e.g., Laurence R. Helfer \& Anne-Marie Slaughter, Toward a Theory of Effective Supranational Adjudication, 107 YALE L.J. 273 (1997).

${ }^{212}$ See Richard S. Kay, The European Human Rights System as a System of Law, 6 CoLUM. J. EUR. L. 55 (2000).

${ }^{219}$ Helfer \& Slaughter, supra note 211, at 314, 323.

${ }^{214}$ Id . at $325-36$.
} 
way, the ECHR's uses of comparative law can give its adjudication more depth, flexibility, and critical self-awareness-all qualities that can contribute to the effectiveness of the Court's work. ${ }^{215}$ The important observation to be added here is that application of the principle of subsidiarity conduces to the practice of cross-judicial communication and comparison. As we saw earlier, subsidiarity encourages the integration of national and supranational normative discourses. In addition, by fostering the conditions for different institutions, national and supranational, to interpret and apply human rights norms to similar situations, it helps to generate the raw material necessary for borrowing and comparison between legal systems to take place at all. Subsidiarity's unity-in-diversity therefore supports the larger goal of a "global community of law," the ultimate foundation of Helfer and Slaughter's criteria for effective supranational adjudication. ${ }^{216}$ Far from posing a threat to the strength of international human rights norms and institutions, subsidiarity in fact contributes on several fronts to the overall factors of effectiveness in international supervision.

The same can be seen at the level of domestic law. The comparison between the ECHR's margin of appreciation doctrine and subsidiarity is relevant here, too. The margin of appreciation enhances the effectiveness of the European Convention on Human Rights not only because it encourages the supranational court to develop the norms incrementally, but also because it brings domestic law and institutions into a deeper and more authentic relationship with the human rights standards in question. By recognizing, in many cases, a significant degree of discretion in local authorities, the ECHR effectively gives room to national institutions to appropriate the Convention and make it their own. They are in a position to take the norms and apply them internally in ways most consistent with their political and institutional structure, their assessment of the needs of a democratic society, and the values of their local culture. Local discretion, in this way, can be a means of absorbing human rights norms more deeply and consistently into society, as opposed to painting human rights law over the surface without any deeper bond to internal traditions. To the extent that subsidiarity can help effect this deeper penetration, it conforms with the aims of securing universal human rights across cultures and nations, and in fact could be indispensable to grounding rights in local social and political practice and thus to guaranteeing their observance more effectively.

This point has vastly more importance outside the European human rights system than within it. In Europe the differences in culture and law, while real, are relatively minor by global standards. ${ }^{217}$ Where the differences among peoples are even greater, the inculturation of human rights is even more necessary to making the norms meaningful and effective. This need is largely underappreciated, even though some human rights scholars and activists have continued to emphasize it. Most notably, Abdullahi An-Na'im, in exploring the relationship of international human rights to Islamic law and culture, has been one of the most consistent and persuasive contributors to our understanding of the urgency of reconciling human rights with local culture to make the former effective. ${ }^{218}$

No element of An-Na'im's insight and argument is limited to the relationship between Islam and human rights. To make human rights effective in any society requires that the norms be accepted and internalized, which in turn depends on local knowledge at several levels-knowledge not only of law but also of norms and their background justifications. ${ }^{219}$

${ }^{215}$ Carozza, supra note 103.

${ }^{216}$ Helfer \& Slaughter, supra note 211, at 367-73, 389-91.

${ }^{217}$ See, e.g., EUROPEAN LEGAL CulturES (Volkmar Gessner et al. eds., 1996).

${ }^{218}$ E.g., Abdullahi A. AN-Na'im, Human Rights in Cross-Cultural Perspectives: A QUest for Consensus (1992); Abdullahi A. An-Na'im, Religion and the Universality of Human Rights, 94 ASIL ProC. 95 (2000); Abdullahi A. An-Na'im, Cultural Transformations and Human Rights in A frica: A Preliminary Report, 11 EMORY INT'L L. REV. 287 (1997); Abdullahi A. An-Na'im, The Contingent Universality of Human Rights: The Case of Freedom of Expression in African and Islamic Contexts, 11 EMORY INT'L L. REV. 29 (1997).

${ }^{219}$ See generally Charles Taylor, Conditions of an Unforced Consensus on Human Rights, in THE EAST ASIAN CHALLENGE FOR HUMAN Rights 124 (Joanne R. Bauer \& Daniel A. Bell eds., 1999). 
As Charles Taylor has explained, the conditions for an unforced consensus on human rights do not lie in the jettisoning of preexisting countervailing traditions but in "creative reimmersions of different groups, each in their own spiritual heritage, traveling different routes to the same goal." 220

Taylor's image of "different routes to the same goal" captures the role that subsidiarity could play in strengthening the effectiveness of human rights: it affirms the aim of human dignity and it protects the integrity of every level of human association by respecting its freedom to take different paths toward that end. Whether at the level of national law or the decisions of international institutions like the European Court of Human Rights, effective action on behalf of human rights depends on their integration with local knowledge. Because subsidiarity is not the same as pluralism tout court but, instead, permits diversity in the achievement of a common end, it aims at allowing just the sort of "creative reimmersion" in to the varied traditions of the human family that our collective experience with human rights has shown to be necessary.

\section{The Legal Objection: The Need for Uniformity, Consistency, and Certainty}

The third basis for concern over subsidiarity and pluralism identified above focuses on the need for uniformity in the interpretation and application of human rights norms as a condition for the realization of the rule of law. Pluralism, it may be said, undermines the stability and predictability necessary for a well-ordered system that seeks justice by ensuring that like cases are treated alike and that legal rules are known with reasonable certainty. As the distinguished comparatist Rodolfo Sacco has recently noted in commenting on diversity and uniformity in the law in Europe, the unification of law

aims to avoid a legal relationship from being regulated in a contradictory way on either side of the Pyrenees, of the Alps, of the English Channel, or the Carpathians. It also aims to avoid the injustice that comes from disparity of treatment and the uncertainties and troubles connected with conflicts of laws that arise when a transnational legal relationship is involved.221

However, Sacco also makes clear, correctly, that the value of uniformity is not absolute. Transnational unification of law has its price as well, such as the dampening of potential innovation and the possible severance of the social and historical roots of the law; diversity, meanwhile, entails correlative benefits. ${ }^{222}$ The choice between the two is not exclusive, but a question of balance, and subsidiarity itself takes that balancing into account, because where the necessity of uniformity across national legal systems clearly outweighs the presumptive benefits of more local lawmaking and interpretation, then the principle of subsidiarity can justify intervention.

In a constitutional system, that balance will necessarily weigh more heavily in favor of uniformity than it would in the international order. A federal system like that of the United States, or a system of overlapping sovereignties like the European Union, may be expected to tend toward less uniformity than a single, undifferentiated constitutional polity; for example, the possibility for legal experimentation, innovation, and adaptation to local circumstances is one of the obvious benefits of such forms of divided sovereignty. In the international sphere, the value of uniformity is diminished even more and the benefits of diversity

${ }^{220}$ Id. at 144; of. Nikhil Aziz, The Human Rights Debate in an Era of Globalization: Hegemony of Discourse, in DEBATING Human Rights 32 (Peter Van Ness ed., 1999).

${ }^{221}$ Rodolfo Sacco, Diversity and Uniformity in the Law, 49 AM. J. CoMP. L. 171, 179 (2001).

${ }^{222}$ See id. 
are more pronounced. Both can be captured by a sufficient appreciation of the extreme difficulty of unification, and therefore of the very high cost that a serious attempt at transnational unification would exact.

Although a significant segment of the discipline of comparative law has often seen itself as being concerned with harmonization of laws, ${ }^{223}$ recently several comparative law scholars have contributed to our understanding of the relationship between law and culture in ways that should seriously undermine any facile assumptions about the possibilities of legal unification. For instance, Vivian Grosswald Curran takes on the methodological presuppositions of the discipline of comparative law; she argues for an approach that stresses the need for cultural immersion and that highlights the persistence of difference across cultures-difference that does not preclude comparison between cultures even while they remain (for Curran) in an ultimate sense incommensurable with one another. ${ }^{224}$ Pierre Legrand makes a complementary argument in the context of the debate over the alleged "convergence" of European legal systems. ${ }^{225}$ Looking at the "deep structures" of European legal systems, Legrand concludes that "the common law mentalité is not only different, but is actually irreducibly different, from the civil law mentalité as found in Continental Europe. These two legal traditions reflect two modes of experiencing the world." ${ }^{226}$ Of course, even if Legrand is right, the divergence of mentalités has not stopped or even slowed the pervasive circulation of juridical models and concepts in Europe. But even in this case, as Gunther Teubner has shown using the example of "good faith" in British law, the importation into a legal system of foreign concepts will frequently end up creating new divergences between the two legal systems involved in the transfer more than unifying them. ${ }^{227}$

Even if the thesis of irreducibility between legal traditions can easily be overstated, ${ }^{228}$ it is still persuasive enough to suggest two conclusions. First, achieving uniformity in law through the relatively benign processes of importation and transplantation of legal norms and concepts, if it is even possible, is likely to be more like the movement of tectonic plates than the movement of consumer goods-it needs space and time in global and epochal proportions. Second, any stronger effort to forge uniformity more immediately out of the divergences of global traditions would necessarily come at the cost of having to exercise vast coercive power-economic, political, and cultural-over and against the deep structures of human culture. The costs of that sort of uniformity in law are obvious, abundant, and extreme: colonialism and tyranny, even to the point of threatening peaceful coexistence.

In the end, then, the legal value of uniformity loses its singular charm among the richer, multitudinous attractions of global cultures. On the one hand, its benefits seem weak, because more superficial forms of "harmonization" do not really bring together legal traditions in a way that realizes the equality and consistency we set out to strengthen. On the other hand, any process that could in fact achieve deeper unification would need to do so at the cost of obliterating cultural difference.

${ }^{223}$ See TOWARDS UNIVERSAL LAW: TRENDS IN NATIONAL, EUROPEAN AND INTERNATIONAL LAWMAKING (Nils Jareborg ed., 1995); David Kennedy, New Approaches to Comparative Law: Comparativism and International Governance, 1997 UTAH L. REV. 545, 608-09.

${ }^{224}$ Vivian Grosswald Curran, Cultural Immersion, Difference and Categories in U.S. Comparative Law, 46 AM.J. COMP. L. 43 (1998).

${ }^{225}$ Pierre Legrand, European Legal Systems Are Not Converging, 45 INT’L \& COMP. L.Q. 52 (1996).

${ }^{226}$ Id. at 63.

${ }^{227}$ Gunther Teubner, Legal Irritants: Good Faith in British Law or How Unifying Law Ends up in New Divergences, 61 MOD. L. REV. 11 (1998).

${ }^{228}$ There is good cause to regard Legrand's argument, in particular, as too broadly and categorically framed, perhaps merely for rhetorical emphasis but perhaps because of a view of the foundations of legal culture as more static and hermetic than is necessary. 


\section{CONCLUSION}

I argued in the preceding section that despite its potential to encourage pluralism in human rights, subsidiarity does not undermine the universal and fundamental nature of human rights in theory, nor the political effectiveness of human rights norms. It respects the inherent problems of unifying law and the value of diversity in legal norms while mitigating the risk that a global rule of law will impose uniformity at the expense of the diversity of human cultures. In fact, as I have suggested at several points, I believe an understanding of human rights and international law that takes subsidiarity seriously into account would actually strengthen human rights in theory and practice. Subsidiarity offers a contrast to prevailing patterns of understanding the place of human rights in the international order, which are based largely on more limited conceptions of sovereignty. It values the freedom and integrity of local culture without reducing particularism to pure devolution and decentralization of authority; it affirms internationalism and intervention without the temptation for a superstate or other centralized global authority. To the extent that there remains disagreement at the end of this discussion about the value of subsidiarity's limited pluralism in human rights, it may well be linked less to a divergence of opinion about the inescapable diversity of the world (which no reasonable observer could deny) than about the comparative danger of hegemonic power in the creation and imposition of international law. Especially in this age of single superpower dominance, the latter is not, in my view, to be taken at all lightly. ${ }^{229}$

A separate, but serious, lingering concern is that it is too easy in words and too hard in practice to maintain both sides of the dichotomies underlying the principle of subsidiarity-that the "locus of paradox" is just a convenient place to hide from hard choices. The problem, one might conclude, is that such a principle is too imprecise and soft, and therefore entirely open to disagreement-a reification of politics as indeterminate as the discourse of human rights itself. In that case, subsidiarity would not contribute anything other than a new vocabulary, a new rhetorical structure, within which to contest the same values and principles that it was meant to address.

The only sure way to address that challenge is to put subsidiarity to the test by seeking to apply it to concrete, "real world" problems. In this article, obviously, I do not pretend to do that work. Instead, I have tried to lay out the conceptual bases and jurisprudential justifications that would make such practical inquiries possible. I do not mean to suggest in any way that intellectual speculation can be considered a substitute for tangible practice. Especially with regard to human rights, where the problems at issue are those so basic to the daily life, well-being, and even survival of flesh-and-blood human individuals and their communities, mere abstractions have led to the oppression of our humanity more often than to its liberation. If the idea of subsidiarity is to help us foster authentic freedom, then, it certainly needs to be subjected to verification in the crucible of our experience. Elsewhere, I have begun to try to do that, for example by identifying and exploring in some detail an approach to strengthening transnational norms regarding the death penalty that consciously relies on the principle of subsidiarity. ${ }^{230}$ However, the space here and the broadly foundational character of this discussion do not lend themselves to taking up other examples with the detail and care needed to consider them well. Reducing the application of subsidiarity to simplistic, mechanical conclusions would in fact contradict its promise of seeking balance among the competing concerns of complex human rights problems.

${ }^{229}$ Cf. Detlev F. Vagts, Hegemonic International Law, 95 AJIL 843 (2001) (assessing legal implications of U.S. hegemony in international law).

${ }^{230}$ Paolo G. Carozza, "My Friend Is a Stranger”: The Death Penalty and the Global Ius Commune of Human Rights, 81 TEX. L. REV. 1031 (2003). 
By way of conclusion, therefore, I offer instead some general reflections on what the work of translating the principle of subsidiarity into human rights practice will require. First, we must remember that subsidiarity is a general principle, not a clear rule. ${ }^{231}$ Even within the existing uses of subsidiarity in the law and politics of the European Union, the principle is clearly not a "hard" enough concept to resolve by itself the complex and multifaceted issues of unity and pluralism that underlie it. ${ }^{232}$ That aspect will apply all the more in the thinner consensus of international law and politics. Subsidiarity by its very terms refers to the need for more contextual, fact-specific decisions, and it necessarily works, if at all, as much or more through rhetoric and politics as through formal doctrine. The detailed criteria by which subsidiarity operates are not suited to abstract reasoning ex ante, but instead need to be worked out over time, and the conclusions to which it leads will always be contextual and dynamic, containing the fluidity and flexibility of phronesis (practical judgment). Therefore, as the relevance of subsidiarity to human rights is worked out in practice, applying it to hard cases will require prudence and openness to reasoned disagreement.

Moreover, nothing should lead us to believe that it will be easy. Subsidiarity cannot be reduced to a simple devolution of authority to more local levels. While it clearly expresses a presumption in favor of the freedom of smaller and more local forms of human association, it does seek to balance both the idea of noninterference and that of intervention or assistance. It therefore requires serious consideration of the ways that more local authorities may sometimes be less capable of ensuring the protection of human rights without external intervention or assistance. The most obvious such local authorities are those who willfully flout the good of the people under their control, the corrupt and criminal regimes responsible for persistent, gross violations of human rights. But other circumstances, perhaps more nuanced, need to be considered too. For example, the nature of the right or the politics of the dispute might make it necessary to remove the interested actors of local politics further from the problem to avoid bias or distortion. Local authorities might not find themselves in a practical position to act conclusively, perhaps because of a lack of necessary experience and expertise or because of structural conditions like marginalization from the global economy. The right at issue might be so central, like freedom from torture, that any local variation at all would inevitably compromise human dignity, or it could be so interconnected with other global concerns that decision and action need to be taken at a higher level. Some of these factors might enter into play for such matters as the rights of aliens and immigrants or minorities, or human rights and biotechnology.

However difficult these assessments may be, understanding, articulating, and developing subsidiarity as a structural principle of international human rights law will allow us to grapple with those rights more adequately, by forcing us to consider fully at what level of society they are most effectively given meaning and real effect. Ultimately, the first and best reason for making that effort is the one with which this discussion began: the mutual concern of subsidiarity and human rights for the dignity of free human persons in society.

\footnotetext{
${ }^{231}$ On the distinction between rules and principles, see RONALD DWORKIN, TAKING RIGHTSSERIOUSLY 23-28, 71-80 (1978).

${ }^{232}$ See de Búrca, supra note 83.
} 